\title{
Biomarkers in cerebrospinal fluid of patients with bipolar disorder versus healthy individuals: A systematic review
}

Ulla Knorr $^{1 *}$, Anja Hviid Simonsen ${ }^{2}$, Henrik Zetterberg ${ }^{3,4,5,6}$, Kaj Blennow ${ }^{3,4}$, Steen Gregers

Hasselbalch $^{2}$, Lars Vedel Kessing ${ }^{1}$

${ }^{1}$ Copenhagen Affective Disorder Research Center (CADIC), Psychiatric Center Copenhagen, Department O, section 6233, Rigshospitalet, Blegdamsvej 9, DK-2100 Copenhagen, Denmark and University of Copenhagen, Faculty of Health and Medical Sciences

${ }^{2}$ Danish Dementia Research Center, section 6922, Rigshospitalet, Blegdamvej 9, DK-2100

Copenhagen, University of Copenhagen, Faculty of Health and Medical Sciences

${ }^{3}$ Institute of Neuroscience and Physiology, Department of Psychiatry and Neurochemistry, the Sahlgrenska Academy at the University of Gothenburg, Mölndal, S-431 80 Mölndal, Sweden

${ }^{4}$ Clinical Neurochemistry Laboratory, Sahlgrenska University Hospital, S-431 80 Mölndal, Sweden

${ }^{5}$ Department of Molecular Neuroscience, UCL Institute of Neurology, Queen Square, London WC1N 3BG, United Kingdom

${ }^{6}$ UK Dementia Research Institute at UCL, London WC1N 3BG, United Kingdom

Corresponding author:

Ulla Knorr, Copenhagen Affective Disorder Research Center (CADIC)Psychiatric Center Copenhagen, Department O, section 6233, Rigshospitalet.

Blegdamsvej 9, DK-2100 Copenhagen, Denmark and University of Copenhagen, Faculty of Health and Medical Sciences. Telephone: +45 38647098. Email: ulla.knorr@ regionh.dk 


\begin{abstract}
Background: The pathophysiological processes of bipolar disorder (BD) may be detectable by the use of cerebrospinal fluid (CSF) biomarkers. Biomarkers for BD may in time assist with diagnosis, prediction of disease course, or identification of response outcome to treatments. Explorative biomarkers have been proposed in many studies but no CSF biomarkers are integrated into routine clinical practice.

Aim: We aimed for the first time to review studies of CSF biomarkers in patients with BD compared to healthy control individuals (HC). We investigated the effect of diagnosis, age, gender, clinical state, medication, technical characteristics of tests, fasting state and, cognitive function if applicable.
\end{abstract}

Method: We did a systematic review according to the PRISMA Statement based on comprehensive database searches for studies on cerebrospinal biomarkers in patients with bipolar disorder versus HC. Risk of bias was systematically assessed.

Results: The search strategy identified X studies of which thirty-four fulfilled the inclusion criteria. A total of 117 unique biomarkers were investigated. Forty biomarkers showed statistically significant differences between BD and HC. Eleven biomarkers were evaluated in more than one study. Only the findings of elevated homovanillic acid and 5-hydroxy-indoleacetic acid were replicated across studies. Most studies had a cross sectional design and were influenced by risk of bias mainly due to small sample size, lack of data on mood state at the time of the CSF puncture and not considering potential confounders including age, gender, diagnoses, BMI, life style factors such as smoking, and psychotropic medication.

Conclusion: Specific monoamine CSF biomarkers may be related to the pathophysiology of BD. Future studies must aim at increasing the level of evidence by validating the positive findings in prospective studies with stringent methodology.

Keywords: Cerebrospinal fluid, bipolar disorder, biomarker, systematic review. 


\section{INTRODUCTION}

Since 1957 when Arvid Carlsson demonstrated that dopamine was a neurotransmitter in the brain $(1,2)$ levels of neurotransmitter precursor and metabolites have been measured in cerebrospinal fluid (CSF) to access central neurochemical function. The pathophysiological processes of several psychiatric disorders may be detectable in CSF. Biomarkers in psychiatric disorders may assist with diagnosis, prediction of disease course, or identification of response outcome to treatments. CSF biomarkers have been proposed in many studies but no CSF biomarkers are integrated into routine clinical practice. Although CSF biomarkers have been investigated in mania and bipolar disorder for more than half century, surprisingly, no exhaustive systematic review has ever been published on CSF biomarkers in BD.

\section{Objectives}

We aimed to systematically review studies of CSF biomarkers in patients with bipolar disorder (BD) versus healthy control individuals (HC). Further, we investigated the effect of age, gender, clinical state, medication, technical characteristics of tests, fasting state and, cognitive function if applicable. Finally, risk of bias was systematically assessed.

\section{METHODS}

\section{Protocol}

A protocol describing methods for the review was prepared and approved by all authors prior to the study. The review is reported according to the PRISMA Statement (3).

\section{Eligibility criteria}

Eligible for review were original studies published in English reporting on levels of biological CSF markers in patients $\geq 18$ years with diagnosis of BD compared to HC. Studies were excluded if: 1) the groups of patients with $\mathrm{BD}$ or the $\mathrm{HC}$ group comprised of less than ten 10 individuals, 2) biomarkers were assessed post-mortem, 3) patients had mixed diagnoses and data regarding patients with BD could not be extracted separately, or 4) the smaller study, when more than one publication reported results regarding identical parameters from the same study population. 


\section{Search}

Studies were identified by conducting a literature search in MEDLINE and PubMed (January 1950 to August 2017) and EMBASE (1974 - August 2017) limits; English language and human, using the following search terms both as keywords and as text words: Cerebrospinal fluid AND bipolar disorder. In addition reference lists of relevant studies were searched by hand.

\section{Study selection and data collection process}

Study titles and abstracts identified by the initial search were screened by UK. Subsequent retrieval of full text articles or other additional information, assessment for eligibility and data extraction was performed independently by two researchers; UK and AHS. Disagreements were resolved by discussion with LVK.

The association between cognitive function in BD and various CSF markers has been sporadically investigated (4-7), but these data were not included in this review.

\section{Data items}

A data sheet was constructed and the following data was extracted: Study identification, age, gender, duration of illness, BD subtype, symptom severity, duration of current affective state, medication use, smoking, alcohol use, BMI, exercise or physical activity, biomarker concentration in CSF, measurement method, blinding of analysts, time of day and fasting state at lumbar puncture. In comparisons between $\mathrm{BD}$ patients and $\mathrm{HC}$, baseline data for BD patients were used from longitudinal studies.

\section{Risk of bias in individual studies}

Tools for assessing quality in observational epidemiological studies has been given less attention compared to tools assessing quality in clinical trials (8). We evaluated five domains as put forward by Sanderson et al. (8): 1) Methods for selecting study participants by appropriate source population and inclusion or exclusion criteria, 2) Methods for measuring exposure and outcome variables by appropriate measurements for both exposure(s) and/or outcome(s), 3) Design-specific source of bias (excluding confounding) by appropriate methods outlined to deal with any design-specific issues such as recall bias, interviewer bias, biased loss to follow up or blinding, 4) Methods to control 
confounding by appropriate design and/or analytical methods, 5) Statistical methods (excluding confounding) by appropriate use of statistics for primary analysis of effect.

\section{RESULTS}

\section{Study selection}

Figure 1 presents an overview of the study selection. The electronic database search in PubMed identified 407 titles. Reviews, meta-analyses, editorials or letters were removed after screening of titles and abstracts ( $n=41)$. Full text assessments of the remaining 366 papers lead to the exclusion of 332 papers. An additional search in EMBASE supplemented by hand searches $(n=3)(9-11)$ yielded no further titles to be included. In summary, 34 studies published from 1968-2017 were included in the qualitative synthesis.

\section{Cerebrospinal fluid biomarkers}

A total of 117 unique biomarkers were investigated in the included studies, see Table 1 . The biomarkers could be categorized into six groups: Monoamine biomarkers (5,12-18), inflammatory biomarkers (19-25), hormone biomarkers (13,26-31), neuropeptide biomarkers $(4,13$ $15,18,19,24,29,32-41)$, metabolomics markers (42), and other biomarkers $(29,43)$.

Overall, statistically significant differences $(\mathrm{P}<0.05)$ between $\mathrm{BD}$ and $\mathrm{HC}$ were found for 40 biomarkers and of these eleven biomarkers were evaluated in more than one study. The results were replicated regarding increased homovanillic acid (HVA) $(5,12,17,18)$ and increased 5hydroxy-indoleacetic acid (5-HIAA) (12,18), and both increased and decreased levels were found between BC and HC regarding, 3-methoxy-4-hydroxy-phenylglycol (MHPG) $(12,18)$ and neural cell adhesion molecule (N-CAM) $(19,25)$. No statistically significant differences were found between $\mathrm{BD}$ and $\mathrm{HC}$ regarding the remaining 77 biomarkers (Table 1).

\section{Monoamines}

Seven monoamine biomarkers were investigated in a total of eight studies including a total of 249 patients with BD and 315 HC (5,12-18) (participants overlap in Sellgren (5) et al and Pålsson et al. (18)). Increased levels were replicated regarding 5-HIAA $(12,18)$ and $\operatorname{HVA}(5,12,17,18)$. These studies were characterized by high numbers of participants $(17,18)$ and subgroup analyses revealed 
higher concentrations of the biomarker among patients of female gender with mania (12) and a history of psychosis $(5,18)$.

Divergent results were found regarding MHPG, since an older study found increased MHPG (12), whereas a recent large study found decreased levels of MHPG (18).

No statistically significant differences between the BD and HC groups were found in four studies regarding 5-HIAA (13-15,17) and in three studies regarding HVA and MHPG (13-15). In a recent study, kynurenic acid (KYNA) was increased in a BD subgroup with a history of psychosis (5), but the finding has not yet been replicated.

Overall, data were conflicting due to smaller studies with no clear information regarding age and gender distributions in the samples (13-15). One study (17) had a HC group significantly younger than the BD group.

\section{Inflammation}

A total of twelve CSF inflammatory biomarkers were investigated in seven studies including a total of 237 patients with BD and 268 HC (19-25). Among inflammatory biomarkers only N-CAM was investigated more than once. Thus, N-CAM levels were increased in a small older study with uneven gender distribution (19) and decreased in a large, recent, age and gender-matched study (25). Highly statistically significant differences were found, but not replicated regarding interleukin (IL)1 $\beta$, IL6 (21), IL8 (22), monocytes chemoattractant protein 1 (23) and, chittinase-3-like protein 1 (23).

No differences between BD and HC were found regarding levels of gamma-globulin (20), variable alternative sliced exon immune-reactive protein (N-CAM VASE) (24), IgG (19), soluble cluster of differentiation 14 (23), and tissue inhibitor of metallo-protease-1 and 2 (23).

\section{Hormones}

A total of 14 hormone biomarkers were investigated in seven studies including a total of 113 patients with BD and $124 \mathrm{HC}(13,26-31)$. Statistically significant differences between BD and HC were found in three smaller studies regarding cortisol (26), melatonin (28), pregnenolone (31), however none of the results were replicated. 
None of the remaining biomarkers differentiated the BD from the $\mathrm{HC}$ groups: Adrenocorticotrophin (ACTH) (14), alfa-melanocytes stimulating hormone (14), atrial natriuretic factor (14), calcitonin (14), corticotrophin releasing factor (CRF) (14), growth hormone (27), norepinephrine (14) progesterone (31), thyrotropin-releasing hormone (30), tyrosine (13) and vasopressin (14).

\section{Neuropeptides}

The results regarding a line of 41 neuropeptide biomarkers were reported in 25 studies including a total of 340 patients with BD and $408 \mathrm{HC}(4,13-15,18,19,24,29,32-41)$. Within the group of neuropeptides statistically significant differences between BD and HC were shown regarding cholecystokinin (CCK) and somatostatin. Thus, CCK was investigated in two older and small studies; one study showed decreased levels of CCK (39) and the other study with no information on age and gender distributions, showed no statistically significant differences between the BD and HC groups (38). Somatostatin was investigated in three smaller, older studies with no information on age and gender. Decreased levels of somatostatin in BD were found in one study (40) and no statistically significant differences between BD and HC were found in two other studies $(14,38)$. Amyloid $\beta$-42 (A $\beta-42)$ was decreased in a small study of late-life BD versus HC (4). Furthermore, in a large study on younger BD and HC (age range 27-50) no statistically significant differences were found regarding $A \beta-42$ (32). A replication of no statistically significant differences between BD and HC was found regarding $\beta$-endorphin (14,34), GABA (13-15), and total CSF protein $(19,24)$.

Recent studies have suggested differences between BD and HC regarding amyloid precursor protein $\alpha$ (32), A $\beta 42 / \mathrm{A} \beta 40$ ratio (32), A $\beta 42 / \mathrm{A} \beta 38$ ratio (32), A $\beta 42 / \mathrm{T}$-tau (4), A $\beta$ 40/P-tau protein (P-tau) ratio (4), glutamine (41), neurofilament light chain (NF-L) (35), secretogranin-II (SgII) (33), and $\mathrm{CSF} /$ serum albumin ratio (37). The results remain to be replicated.

\section{Metabolomics}

A recent study of a panel of metabolomics biomarkers in 54 BD males versus 40 HC males (42) found thirteen statistically significantly altered biomarkers: Uric acid, fructose 6-phosphate, ribose 5-phosphate, CoA, 2-oxoisovaleric acid, lactic acid, pyruvic acid, citric acid, isocitric acid, cisaconitic acid, urea, alanine, and tryptophan. After multivariate logistic regression with adjustments for BMI only CSF isocitric acid levels were statistically significantly higher in BD versus HC.

\section{Other}


A highly statistically significant difference between ten patients with BD and ten HC was found for sorbitol, but not for glucose (43). The results have not yet been replicated. Results regarding magnesium did not differentiate between 130 patients with BD and $59 \mathrm{HC}$.

\section{Risk of bias}

The following study characteristics were identified to have an effect on the results in one or more studies: 1) study design, 2) sample size of study participants, 3) diagnosis, 4) symptoms, 5) inclusion and exclusion criteria, 6) age, 7) gender, 8) height and weight, 9) medication, 10) smoking, and 11) ethnicity/genetic, 12) statistics, and regarding the biomarkers 13) pre-analytical factors, 14) methods for biomarker analyses.

1) Study design.

The patients were selected from both inpatient $(29,30,36,38)$ and outpatient wards (36). A possible effect of hospitalization was rejected by Koslow et al. (12). The included studies were all cross sectional case-control studies. Some authors included follow-up data of subsets of the BD participants in order to reveal effects of medication (17,27,29-31). Berrettini et al. made an attempt to assess the stability of GHRH over time by repeating CSF GHRH in 11 of $37 \mathrm{HC}$ after a time span of 3 weeks to two years and found a statistically significant correlation between the first and the second lumbar puncture (27). No other studies reported longitudinal follow-up of the HC group. Thus, no evidence regarding stability of the biomarkers was given among $\mathrm{HC}$ or BD in repeated measures in a larger sample.

\section{2) Sample size.}

The size of the study samples ranged from 10 to139 patients with bipolar disorder and 10 to113 healthy control individuals. A majority of the studies were small ( $<30 \mathrm{BD})$, though contrasted by the larger cohorts from the St Göran Bipolar Project including 139 patients with BD and 113 HC $(5,18,21-23,32,35,41,42)$, the studies by George et al. including 76 patients with BD and $59 \mathrm{HC}$ $(29,31)$, and further the recent study by Hidese et al. including 57 patients with BD and $111 \mathrm{HC}$ (25). Small studies increase the risk of both type 1 and 2 errors. Lack of power may specifically have contributed to no statistically significant differences found in the studies of HVA (13-15), dihydroxy-phenyl-acetic acid (DOPAC) (14) and dopamine sulfate (DPS) (14). 


\section{3) Diagnosis.}

In case control studies it is obviously important that the segregation of the groups is strict in order to avoid systematic errors. Diagnosis of bipolar disorder was thorough across the studies: DSM III $(19,24,30)$, DSM IV $(4,5,15,18,21-25,28,30,32,33,35,37,41,42)$, specified by Research Diagnostic Criteria (44) $(13,16,26,29-31,34,36,38,40,43)$. Besides information on BD, demographical information, other clinical parameters as duration of illness, duration of current affective state, smoking have been reported in newer studies and may influence findings.

The healthy control groups were often not described in ways that permit its replication. A line of authors reported that $\mathrm{HC}$ were retrieved by newspaper advertisement $(12,15,25,29,31)$, among colleges at hospitals $(5,17,20,21)$, or via national registers $(5,18,21-23,32,35,41,42)$. The selection of healthy control individuals for studies of BD is important, since BD often presents with minor psychiatric disorders prior to the onset of the first hypomania or mania. Thus, a healthy control group that includes participants with past minor depressive episodes, isolated episodes of panic disorder, eating disorders, or obsessive compulsive disorder that had remitted spontaneously or with psychotherapy counseling (32) may be problematic and lead to overlooking CSF markers as the HC group may present with deviations in CSF markers similar to those in BD groups.

\section{4) Mood episodes, symptoms and subtypes of BD.}

BD patients presented with all types of mood episodes in the included studies. Thus, data could be extracted from the papers regarding patients grouped as mania $(12,13,16,17,20,26,34,38,40)$ or as bipolar depressed $(15,39,40)$. Regarding MHPG Koslow et al. found statistically significant differences between patients with mania and $\mathrm{HC}$, but they found no changes between BD as a group and HC (12). One could suggest that CSF biomarkers differ during mania and depression, but data did not support this. A line of studies investigated patients with either BD type I or type II $(5,19,21-24,28,29,31-33,35,37,41,42)$ and different results for the two subtypes were found regarding CSF Neural cell adhesion molecule (N-CAM) levels (19) and secretogranin-II (33). A number of studies did not specify the subtype of $\operatorname{BD}(14,27,28,30,36,43)$, and the St. Göran cohort included a small number of patients with other affective diagnoses including cyclothymia and schizo-affective disorder (5).

When patients are examined in the euthymic state, CSF markers may reflect trait markers $(45,46)$, however the definition of euthymia differs across studies. The St. Göran cohort included patients 
with BD in a euthymic state defined as a scores below 14 on both Montgomery-Åsberg Depression Rating Scale and Young Mania Rating Scale (33) at the date of spinal tap. Berrettini et al. included patients that were euthymic by history and clinical observation for a minimum of four weeks prior to study (36). Mann et al recruited a group of patients with BD being currently euthymic during the previous month, as assessed by a maximum score of 7 in the 21-item Hamilton Rating Scale for Depression (HAMD), and a maximum score of 4 in the Young Mania Rating Scale (15).

Regarding monoamines, subgroup analyses of clinical features of the BD revealed that the severity of the disorder (or a factor related to severity) may be important to consider, as the most extreme biomarker levels were found among participants with BD type I $(5,12)$. The effect of specific symptoms was explored by Berettini et al, who found no differences between small subgroups with $(n=6)$ and without $(n=20)$ a history of suicidality in relation to CSF DOPAC, DPS, HVA, MHPG, $\mathrm{ACTH}, \alpha$-melanocyt stimulating hormone, atrial natriuretic factor, calcitonin, $\mathrm{CRF}$, norepinephrine, vasopressin, $\beta$-endorphine, $\beta$-lipoprotein, calmodulin, GABA, n-terminal fragment of propiomelatonocortin, and neurotensin (14). Furthermore, psychotic features differentiated participants from those with no psychotic features in various CSF markers including HVA (5) and KYNA (18). An effect of diagnostic subtype was shown for SG-II (33), thus higher levels were found regarding BD type I compared with to BD type II. George et al. found no correlation between magnesium levels and severity of depression or mania, on the day of the lumbar puncture (29). In a longitudinal study of nine patients Rubinow et al. showed a statistically significantly lower CSF somatostatin level $(\mathrm{P}<0.02)$ during depressed states compared to those in manic or improved states (40). Finally, the sAPP- $\alpha$ and $\beta$ concentrations were negatively associated with co-morbid anxiety (32). In conclusion symptoms may affect a CSF biomarker.

5) Inclusion and exclusion criteria.

Recent studies clearly reported criteria regarding BD participants, whereas older studies were not that clear, which complicates replication of the results.

6) Age.

Most studies attempted age- and gender matching between BD and HC. However, as can be seen from Table 1, it was not always possible to extract the precise data. Participants' ages ranged from below 20 years (17) to 81 years (4). Examples of effects of age were seen, e.g., a statistically significant effect of postmenopausal status in women was shown on CSF MHPG, whereas no effect 
of age was found in men (12). Furthermore, CSF magnesium did not change as a function of age (29). The A $\beta 42 / A \beta 38$ was negatively associated with age as found by Jakobsson et al. (32). Thus, age may affect a CSF biomarker.

7) Gender.

Participants were of both genders in all but two papers that included men only $(21,42)$. In a line of studies no precise information on gender could be extracted from the papers $(5,12-$

$15,17,19,20,28,30,35,36,38-41)$. George et al. found that CSF pregnenolone was non-significantly lower in all women. No differences were found in CSF progesterone or neuropeptide diazepam binding inhibitor (DBI) (31). Koslow et al. found decreased HVA in five females with mania compared to 32 female HC (12). George et al reported levels of CSF magnesium were significantly higher in men than in women ( $<$ 0.05) (29). Frye et al. (30) found a gender difference (female lower), $\mathrm{P}<0.05)$ regarding CSF thyrotropin-releasing hormone (TRH). The sAPP- $\alpha$ and $\beta$ concentrations were positively associated with male gender in BD (32). Thus, gender may affect a CSF biomarker.

8) Height and weight.

The sAPP- $\alpha$ and $\beta$ concentrations were negatively associated with BMI in BD (32) and BD tended to have higher BMI than HC (32). Berretini et al. found a statistically significant effect of bodyweight regarding CSF GHRF (27). Palsson et al. found statistically significant effects of height and BMI on CSF glutamate markers (41). Thus, height and weight may affect a CSF biomarker.

9) Medication.

In a total of 15 studies the patients with BD were drug free at the time of the lumbar puncture (12$16,24,26,27,29,31,34,36,38-40)$ and statistically significant differences were found regarding cortisol (26), pregnonolone (31) and, somatostatin (40). In the remaining 19 studies the patients received medication at the time of the lumbar puncture $(4,5,17-23,25,28,30,32,33,35,37,41-43)$.

Regarding lithium Berrettini et al. found that lithium treatment was associated with increased CSF 5-HIAA ( $\mathrm{P}=0.05)$ (47) and no association was seen with GABA (48). Results from the St Gøran study showed that in patients with BD CSF IL8 (22), glutamine and D-serine levels were positively associated with lithium treatment (41). Berrettini et al. found no effect of lithium on GHRF levels in 13 patients with BD who provided both a CSF sample on lithium, and a second CSF sample, after a 
minimum of two weeks off lithium (27). Further, no statistically significant differences were found in CSF serum/ albumin ratio (37) or CSF magnesium concentrations (29) regarding lithium among patients with BD.

Regarding antipsychotics Zetterberg et al. found statistically significant differences regarding $\mathrm{CSF} /$ serum albumin ratio between $\mathrm{BD}$ on antipsychotics compared to $\mathrm{BD}$ on other treatments (37). Isgren et al. reported that increased CSF IL8 in BD was positively associated with antipsychotic treatment (22).

As for anticonvultants Palsson et al. found that CSF glutamine and D-serine levels were positively associated with valproate and furthermore, CSF L-serine was associated with lamotrigine (41). Frye el al. (30) obtained a second lumbar puncture after six weeks of a blinded study with carbamazepine ( $\mathrm{n}=15$ BD patients), lamotrigine ( $\mathrm{n}=10$ BD patients), and no significant changes were found on TRH. There were no statistically significant differences in CSF/serum albumin ratio regarding anticonvulsants (37). George et al. found no association with carbamazepine ( $\mathrm{n}=32 \mathrm{BD}$ patients) and CSF magnesium concentrations (29).

Regarding other types of medication, Sjöström et al. (17) did a second lumbar puncture (LP) 7-10 days after the first LP to test the effect of probenecid and methylperidol versus treatment as usual in an experimental trial. In HC, 5-HIAA increased by 60\% ( $\mathrm{P}<0.01)$ and HVA by $200 \%(\mathrm{P}<0.02)$ after probenecid, and a further effect was found regarding 5-HIAA, but not regarding HVA by the addition of methylperidol. The increases after probenecid were lower in the BD group, 20\% regarding HVA and 73\% regarding 5-HIAA, Frye el al. (30) found no change in CSF TRH obtained after six weeks on nimodipine $(n=16)$, gabapentin $(n=10)$, venlafaxine $(n=13)$, or bupropion $(n=13)$. There were no statistically significant differences in CSF/serum albumin ratio regarding anxiolytics, and antidepressants (37). The sAPP- $\alpha$ and $\beta$ concentrations were negatively associated with the use of benzodiazepines and positively associated with the use of mirtazapine (32). Regenold et al. found no association with medication on sorbitol (43).

In order to combine data regarding medicated patients Hidese et al. converted daily doses of antipsychotics to chlorpromazine-equivalent doses and those of antidepressants were converted to imipramine-equivalent doses according to a published guideline for Japanese $(25,49)$. Hidese et al. found no statistically significant differences in N-CAM between drug free and medicated patients with BD (25). 
Furthermore, the studies included in this review did not allow an analysis of potential confounding by indication. Patients with BD type I may more often be treated with lithium, divalproate and antipsychotics whereas lamotrigine and antidepressants will be used more extensively in patients with BD type II (50). Poltorak et al. reported that three samples were available from a single patient before and after electroconvulsive therapy (ECT). The CSF concentrations of total N-CAM were decreased by $40 \%$ after a course of 16 bilateral treatments (19). In conclusion, ECT and medication may influence levels of a CSF biomarker.

10) Smoking.

Smoking is often more common in patients groups than among HC (e.g. Jakobsson et al. (33)) and smoking status has previously been associated with CSF biomarker levels of amino acids in CSF (51). However, Pålsson et al. found that adding smoking as a co-variate did not explain observed differences between BD and HC for glutamate markers (41). Thus, smoking may affect a CSF biomarker.

11) Ethnicity/genetics.

Data in this review derived from studies conducted in USA (National Institute of Health hospitals) (12-16,19,24,26,27,29-31,34,36,38,40,43), Brazil (4), Japan (25), Belgium (39), Germany (28) and Sweden $(5,17,18,20-23,32,33,35,37,41,42)$. Regenold et al. found that concentrations of sorbitol did not differ significantly when all subject were grouped by race, i.e. African-American versus white (43). However, it is not clear how ethnicity may influence results as no clear pattern appears across these study groups. Further, potential effects of some genetic variations have been investigated. A statistically significant association was found between the risk allele in rs1006737 SNP and a decreased CSF $\mathrm{P}$ tau/T tau ratio in $\mathrm{BD}$, thus linking variation in the $C A C N A 1 C$, encoding the alpha 1C subunit of the L-type voltage-gated calcium channel (52). To elucidate the genetic variability underlying individual levels of CSF KYNA in BD, Sellgren et al. conducted a genome-wide association study against CSF KYNA and found one SNP (rs 10158645 at 1p21.39) that reached genome-wide statistical significance (5). Due to heritability of BD a family history of BD and schizophrenia was used in a line of studies, e.g. (41).

12) Statistics. 
Three projects reported extensively on different markers obtained in the same participants described in different papers: Berrettini et al. studies (14,27,36), National Institute of Mental Health - Clinical Research Branch studies (12,19,24,40,53), and St. Göran Bipolar Project (5,18,2123,32,35,41,42). Thus, there is an increased risk of chance findings due to multiple testings (i.e., a type 1 error). Thus, Palsson et al. found that the mean concentration of glutamine (adjusted for age, sex, BMI and height) was significantly higher in $\mathrm{BD}$ than in $\mathrm{HC}(\mathrm{P}=0.0026)$. However, this difference did not survive correcting for multiple testing (18). Highly statistically significant findings $(\mathrm{P}<0.001)$ were found in other studies regarding increased HVA (5), 5-HIAA (18), IL-1 $\beta$ (21), IL-8 (22), A $\beta-42 / T$-tau ratio (4), NF-L (35), isocitric acid (42), and decreased somatostatin (40), decreased IL-6, (21), melatonin (28) suggesting that these were not chance findings. However, highly statistically significant findings regarding MHPG were pointing in different directions. Thus, levels of MHPG in BD versus HC were increased in one study (12) and decreased (18) in another.

13) Pre-analytical sampling and storage of CSF.

Most studies report that the biomarkers were collected in the morning under standardized conditions, such as fasting, lateral decubitus or sitting position, storage of CSF at minus 70-80 degrees and authors provided a precise description of the methods used to handle the CSF. Regarding CSF GHRF Berretini et al. (27) found no evidence of a rostro-caudal gradient as proposed by Gjerris et al. (54). Few studies gave information of the type of containers used for sampling and storage, e.g. polypropylene tubes $(4,14,42)$ or low protein absorption tubes $(25)$, types of needles (25), and whether blood contaminated CSF samples were included $(17,18,43)$. Authors reported blinding of readers of the cerebrospinal fluid marker and the diagnosis of the participants in five studies, only $(12,13,29,34,37)$. In most studies it was unclear if the CSF was collected at the same time the diagnosis was given. Bipolar patients may have rapid changes from euthymia to depression or hypomania or mania, thus information regarding the timespan between assessment of the diagnosis and the collection of CSF is important as CSF markers may vary with affective states. Furthermore, it is unclear in most studies whether data collection was planned prospectively or retrospectively. Finally, no authors gave information on the frequency of side effects following lumbar puncture in the research setting. A precise description of the methods is important when attempts are made to replicate findings.

14) Analytics. 
Multiple different methods have been used to analyze biomarkers in the included studies of this review: Protein clusters (55), metabolomics (42), radio-immuno assays $(26,27,30,31,33,34,36,39,40)$, radio receptor assays (RIA) (34), enzyme-linked immunosorbent assays $(23,25,28,35)$, various immune assays $(4,5,21,22,32,37,38)$, high performance liquid chromatography (HPLC) $(5,16,31,41)$, gas chromatographic (GC) mass spectrometric $(12,43)$, Western blots (19). As mentioned previously, increased concentrations of HVA was found in BD compared with $\mathrm{HC}$ in three studies. The results were in concert even though they used different methods: Sjøstrøm et al. used a fluorometric method (17), Koslow et al. used a modification of the GC - mass spectrometric procedures by Fri et al and Swahn et al. (12), and Pålsson et Sellgren et al. used HPLC with electrochemical detection $(5,18)$. Berrettini et al. and Mann et al. also used HPLC, but their results regarding HVA did not separate BD from HC $(14,15)$.

Increased concentrations of 5-HIAA were found between BD and HC in two studies that used different analytical methods, thus Koslow et al. used a modification of the GC - mass spectrometric procedures by Fri et al and Swahn et al. (12), and Pålsson et al. used HPLC with electrochemical detection (18). Berrettini et al. (14) and Mann et al. (15)also used HPLC, and their results regarding HIAA, did not separate BD from HC (14).

MHPG results where not in concert eventhough HPLC was used by four groups (12-15). Divergent statistically significant results were provided regarding Neural cell adhesion molecule (N-CAM), which was analysed with the use of Western blots by Poltorak et al. (19), and with an ELISA technique by Hidese et al. (25).

A 342 , P-tau and T-tau protein (Innobia Alz/Bio3 kits) (4,32), somatostatin (RIA) $(14,38,40)$, were analyzed by similar techniques, but the results were divergent.

No statistically significant differences were found regarding GABA in three studies using different techniques including Ion-exchange flurometric measurements (13), HPLC (14), and GC- mass spectrometric (15). Furthermore, $\beta$-endorphines were analyzed with RIA in two studies $(14,34)$, and both studies found no statistically significant differences between BD and HC.

\section{CSF markers in relation to blood-based markers}


Lumbar puncture is time consuming and the participants may suffer side effects (e.g. headache). If CSF markers correlate with blood markers it would be an obvious clinical advantage to use blood markers. Data is limited in the included studies, though Jakobsson et al. found no correlation between blood high-sensitivity C-reactive protein and CSF inflammatory markers and stresses the importance of complementing blood analyses with CSF analyses to elucidate brain-specific inflammatory mechanisms (23). Bumb et al. found decreased melatonin in CSF in BD but not in serum (28). For proteins that are highly expressed in extracerebral tissues little correlation of their blood concentration with CSF can be expected. However, some brain-derived proteins, e.g., tau and NFL, can now be measured in blood using ultrasensitive technologies (ref:

https://www.ncbi.nlm.nih.gov/pmc/articles/PMC4941042/). Plasma/serum and CSF concentrations of NFL correlate (ref: https://www.ncbi.nlm.nih.gov/pmc/articles/pmid/26870824/; https://www.ncbi.nlm.nih.gov/pubmed/27071153) and plasma/serum NFL would be highly interesting to examine in the context of $\mathrm{BD}$ and medications.

\section{Comparisons to other diagnostic groups}

A line of the included studies examined biomarkers across diagnostic groups: Schizophrenia (13,15,16,20,24-26,34,38,39), ADHD (41), major depression (25,28,30,31,38-40,43), confusion (20), neurosis (20), alcoholism (20), psychopathy (20), anorexia nervosa (26,38), mild cognitive impairment/ dementia (4) and Parkinson (39).

\section{DISCUSSION}

This review aimed at providing an exhaustive review of the exciting literature regarding cerebrospinal biomarkers in patients with BD versus HC. A total of 34 case-control studies investigated 117 unique biomarkers that could be divided into the following groups: Monoamines, hormones, inflammation, neuropeptides, metabolomics and others. A statistically significant difference between biomarker concentrations in BD and HC were found regarding 40 biomarkers. Increased levels of the monoamines HVA and 5-HIAA were replicated across studies.

A large proportion of the statistically significant differences in CSF biomarkers between BD and HC derived from 19 studies where the patients received medication for BD whereas only three biomarkers showed statistically significant differences between drug free BD and HC. Medication 
may influence levels of the biomarker in CSF and it may be a risk of bias along with age, gender, smoking, height, weight, symptoms and diagnoses (BDI/BDII). Further, the stability of biomarkers in $\mathrm{BD}$ and $\mathrm{HC}$ has not received much attention yet and variation i.e. by season, new episodes and symptom levels are possible risk of bias that could be investigated in longitudinal studies.

When biomarker levels are different between patients with a specific disorder and healthy control individuals in a cross sectional case-control study it is unknown whether the identified biomarker is causing the condition or is a result of the condition, or both. Is the biomarker related to the mood disorder itself or is it a compensatory response to maintain homeostasis with potential therapeutic benefits? These questions can be addressed in longitudinal study designs.

\section{Conclusion}

In summary, although cerebrospinal biomarkers in BD versus $\mathrm{HC}$ have been investigated during six decades the level of evidence is surprisingly low. The highest level of evidence was reached for the monoamines HVA and 5-HIAA, since data were replicated in different cohorts. Thus, an imbalance of monoamines may relate to the pathology of BD. A total of 77 of the studied CSF biomarkers did not differentiate between BD and HC. Most studies were influenced by risk of bias mainly due to small sample size, lack of data on mood state at the time of lumbar puncture and not considering potential confounders including age, gender, BMI, life style factors such as smoking, and psychotrophic medication.

The available evidence derives largely from case control studies and only some studies supplemented data by follow-up data of subsets of the BD participants that $(4,12,15,17,20,27,29$ $31,34,40,43)$ revealed effects of medication and electro convulsive therapy. However, at the moment several groups are investigating different cohorts so future larger longitudinal studies with strict methodology will increase the level of evidence towards revealing the pathology of bipolar disorder that may likely implicate multiple biomarkers.

\section{Funding}

Ulla Knorr is appointed as associated research professor at University of Copenhagen and Mental Health Services - Capital Region of Denmark. Anja Hviid Simonsen is funded by Absalonfonden. Henrik Zetterberg is a Wallenberg Academy Fellow and receives funding from the Swedish and 
European Research Councils, Swedish State Support for Clinical Research (ALFGBG),

Frimurarestiftelsen and the Knut and Alice Wallenberg Foundation.

\section{Conflict of interests}

Henrik Zetterberg has served at advisory boards of Eli Lilly, Roche Diagnostics, has received travel support from TEVA, and is a co-founder of Brain Biomarker Solutions in Gothenburg AB, a GU Ventures-based platform company at the University of Gothenburg. 
Figure 1: PRISMA Flow Diagram

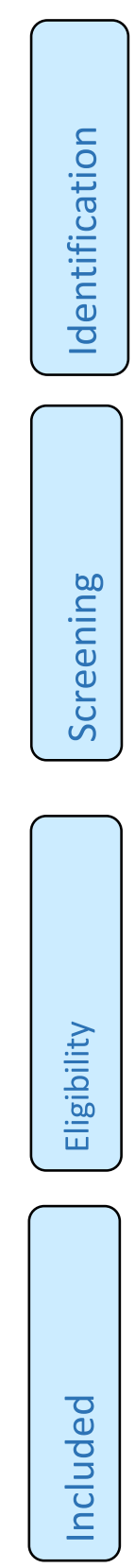

Records identified through database searching in Medline

$(n=407)$
Additional records identified

through other sources

$(n=3)$

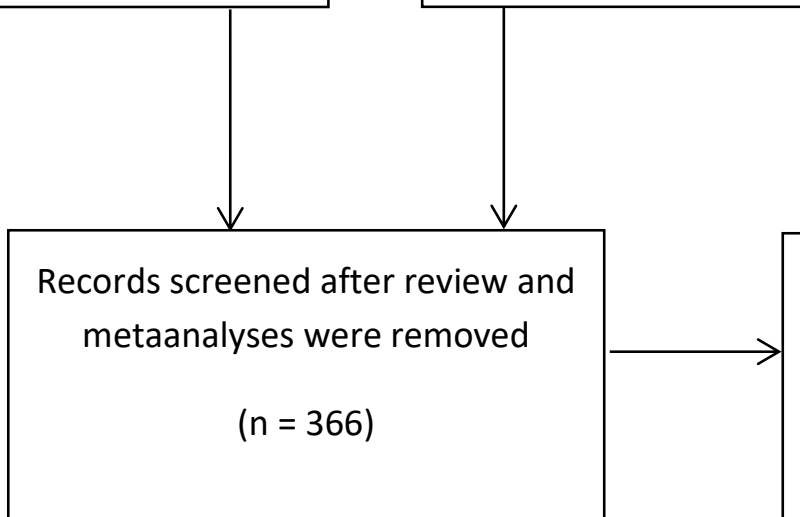

Records excluded after

initial screening of titles and abstracts

$(n=44)$

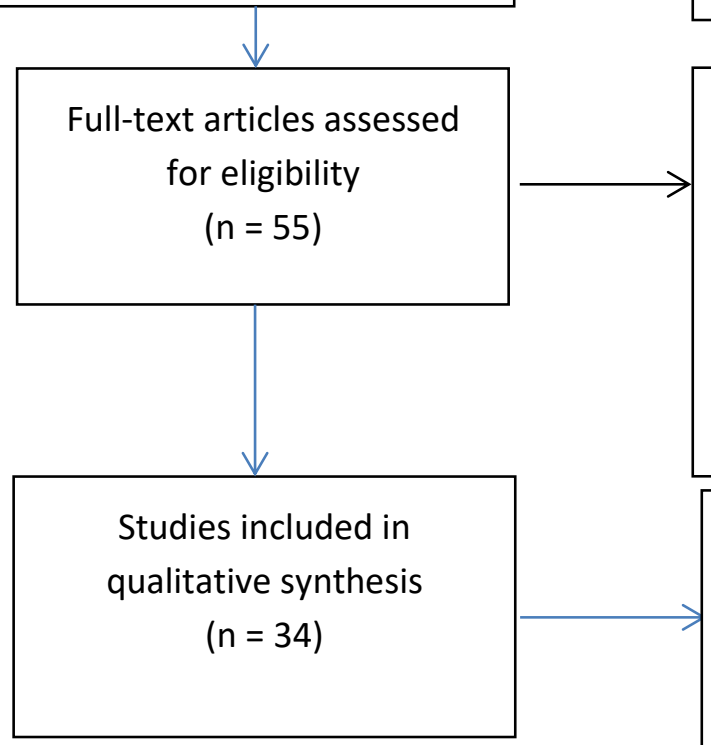

Excluded full-text articles $(n=311)$ :

Not concerning BD ( $n=56)$, no CSF biomarker $(n=44)$, participants $n<10$ ( $n=62)$, no HC ( $n=126)$, post-mortem brain samples $(n=8), B D$ data could not be extracted $(n=10)$, and animal studies $(n=5)$

Additional records excluded due to repeated reporting $(n=21)$ 


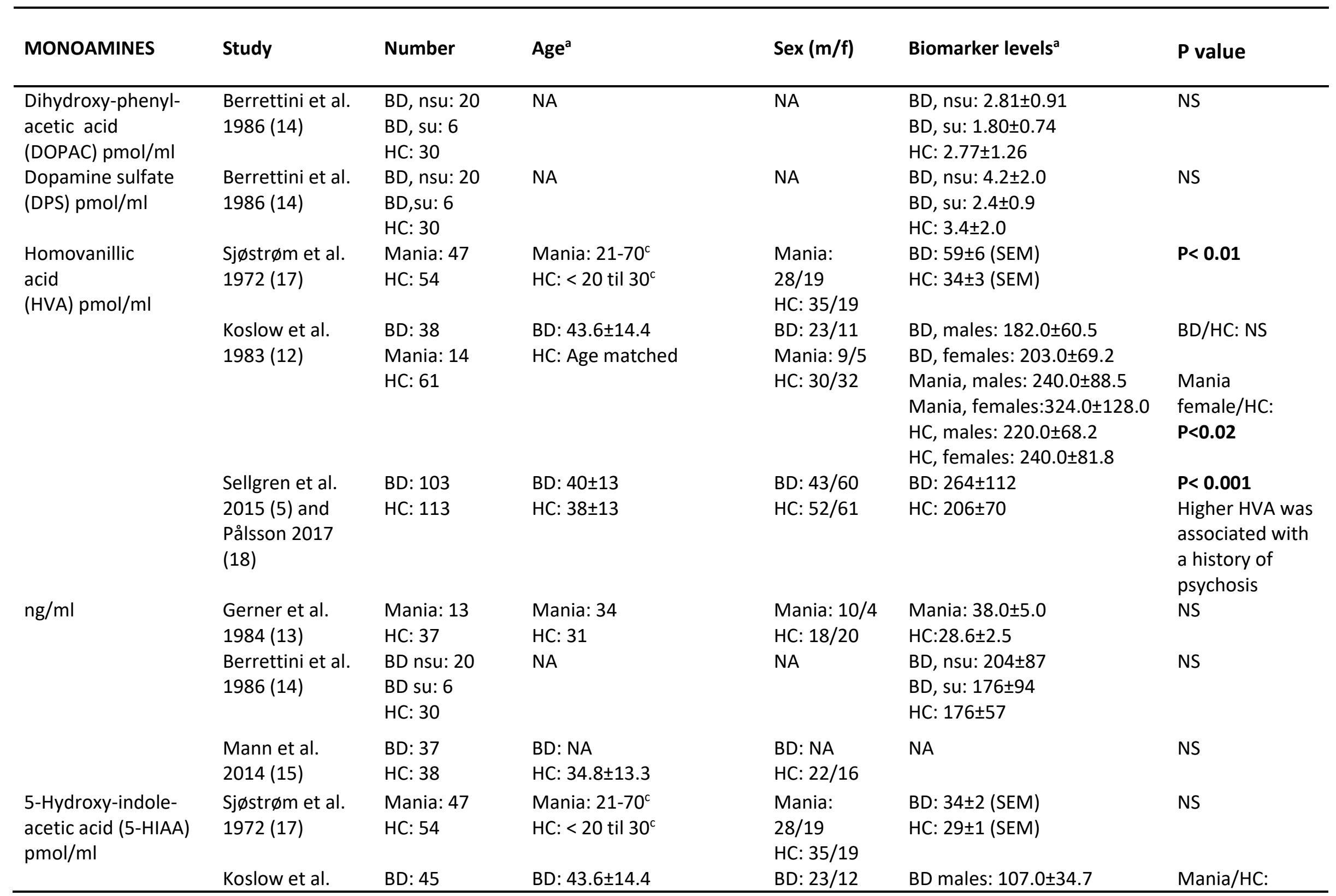




\begin{tabular}{|c|c|c|c|c|c|c|}
\hline & $1983(12)$ & Mania: 14 & HC: Age matched & Mania: $9 / 5$ & BD females: $122.0 \pm 31.4$ & $P<0.02$ \\
\hline & & HC: 58 & & HC: $29 / 29$ & $\begin{array}{l}\text { Mania, males: } 118.0 \pm 43.6 \\
\text { Mania, females: } 161.0 \pm 41.2 \\
\text { HC, males: } 108.0 \pm 22.5 \\
\text { HC, females } 114.3 \pm 37.1\end{array}$ & $\begin{array}{l}\text { Mania, } \\
\text { females/HC: } \\
\mathrm{P}<0.01 \\
\text { Mania, } \\
\text { males/HC: NS }\end{array}$ \\
\hline \multirow[t]{9}{*}{$\mathrm{ng} / \mathrm{ml}$} & Gerner et al. & Mania: 13 & Mania: 34 & Mania: NA & Mania: $22.8 \pm 2.9$ & NS \\
\hline & $1984(13)$ & HC: 37 & HC: 31 & HC: NA & $\mathrm{HC}: 22.2 \pm 1.8$ & \\
\hline & Berrettini et al. & BD, nsu: 20 & NA & NA & BD, nsu: $98 \pm 31$ & NS \\
\hline & $1986(14)$ & BD, su: 6 & & & BD, su: $105 \pm 49$ & \\
\hline & & HC: 30 & & & HC: $72.3 \pm 21.3$ & \\
\hline & Mann et al. & BD: 37 & BD: NA & BD: NA & BD: NA & NS \\
\hline & $2014(15)$ & HC: 38 & HC: $34.8 \pm 13.3$ & HC: $22 / 16$ & HC: NA & \\
\hline & Pålsson 2017 & BD: 103 & BD: $40 \pm 13$ & BD: $43 / 60$ & BD: $116 \pm 42$ & $P<0.001$ \\
\hline & $(18)$ & HC: 113 & HC: $38 \pm 13$ & HC: $52 / 61$ & HC: $98 \pm 31$ & \\
\hline Indole-3-acetic & Anderson et al. & Mania: 10 & Mania: $30.7 \pm 9.7$ & Mania: $7 / 3$ & Mania: $4.32 \pm 0.63$ & NS \\
\hline Acid (IAA) ng/ml & $1984(16)$ & HC: 36 & HC: $31.1 \pm 11.3$ & HC: $7 / 19$ & HC: $4.39 \pm 0.37$ & \\
\hline \multirow{5}{*}{$\begin{array}{l}\text { Kynurenic acid } \\
\text { (KYNA) nM }\end{array}$} & Sellgren et al. & BD, no & NA & NA & BD no psychosis: & BD no \\
\hline & $2015(5)$ & psychosis: 40 & & & $1.72 \pm 0.12^{d}$ & psychosis/ HC \\
\hline & & BD, psychosis: & & & BD psychosis: & NS \\
\hline & & 36 & & & $2.08 \pm 0.18^{d}$ & BD psychosis/ \\
\hline & & HC: 46 & & & HC: $1.6 \pm 0.10^{d}$ & HC: $\mathbf{P}<0.05$ \\
\hline \multirow{12}{*}{$\begin{array}{l}\text { 3-Methoxy- } \\
\text { 4-hydroxy- } \\
\text { phenylglycol } \\
\text { (MHPG) pmol/ml }\end{array}$} & Berrettini et al. & BD nsu: 20 & NA & NA & BD nsu: $51.9 \pm 27.0$ & NS \\
\hline & $1986(14)$ & BD su: 6 & & & BD su: $42.7 \pm 6.1$ & \\
\hline & & HC: 30 & & & HC: $44.7 \pm 7.6$ & \\
\hline & Koslow et al. & BD: 38 & BD: $43.6 \pm 14.4$ & BD: $23 / 11$ & BD: $46.2 \pm 11.2$ & Mania/HC: \\
\hline & $1983(12)$ & Mania: 14 & HC: Age matched & Manic: 9/5 & Mania: 59.9 \pm 19.6 & $P<0.0001$ \\
\hline & & HC: 61 & & HC: $30 / 31$ & HC: $43.3 \pm 8.4$ & BD/HC: NS \\
\hline & Gerner et al. & Mania: 14 & Mania: 34 & Mania: 10/4 & Mania: $45.9 \pm 2.1$ & NS \\
\hline & $1984(13)$ & HC: 34 & HC: 31 & HC: NA & HC: $42.0 \pm 2.1$ & \\
\hline & Mann et al. & BD: 37 & BD: NA & BD: NA & NA & NS \\
\hline & $2014(15)$ & HC: 38 & HC: $34.8 \pm 13.3$ & HC: $22 / 16$ & & \\
\hline & Pålsson 2017 & BD: 103 & BD: $40 \pm 13$ & BD: $43 / 60$ & BD: $38 \pm 8$ & $P<0.001$ \\
\hline & (18) & HC: 113 & HC: $38 \pm 13$ & HC: $52 / 61$ & $\mathrm{HC}: 42 \pm 7$ & \\
\hline
\end{tabular}


HC: Healthy control, Nsu: No suicidality, Su: Suicidality, NS: Non statistically significant, NA: Not applicable, Hosp: Hospitalized, Not-hosp: Not hospitalized

${ }^{\mathrm{a}:}$ : Median \pm SD, ${ }^{\mathrm{b}}:$ Median (interquartile range), ${ }^{\mathrm{c}}:$ Range, ${ }^{\mathrm{d}}:$ Standard error of the mean

\begin{tabular}{|c|c|c|c|c|c|c|}
\hline INFLAMMATION & Study & Number & $\mathrm{Age}^{\mathrm{a}}$ & $\operatorname{Sex}(m / f)$ & Biomarker levels ${ }^{b}$ & $P$ value \\
\hline $\begin{array}{l}\text { Interleukin-1 } \\
(\mathrm{IL}-1 \beta) \mathrm{pg} / \mathrm{mL}\end{array}$ & $\begin{array}{l}\text { Søderlund et al. } \\
2011(21)\end{array}$ & $\begin{array}{l}\text { BD I: } 15 \\
\text { BD II: } 15 \\
\text { HC: } 30\end{array}$ & $\begin{array}{l}\text { BD: } 43,2 \pm 13,5 \\
H C: 25.4 \pm 7.2\end{array}$ & $\begin{array}{l}\text { BD: } 30 / 0 \\
\text { HC: } 30 / 0\end{array}$ & $\begin{array}{l}\text { BD: } 4,2 \pm 0,5^{d} \\
\text { HC: } 0,8 \pm 0,04^{d}\end{array}$ & $P<0.001$ \\
\hline $\begin{array}{l}\text { Interleukin } 6 \\
\text { (IL-6) pg/ml }\end{array}$ & $\begin{array}{l}\text { Søderlund et al. } \\
2011(21)\end{array}$ & $\begin{array}{l}\text { BD I: } 15 \\
\text { BD II: } 15 \\
\text { HC: } 30\end{array}$ & $\begin{array}{l}\text { BD: } 43,2 \pm 13,5 \\
H C: 25.4 \pm 7.2\end{array}$ & $\begin{array}{l}\text { BD: } 30 / 0 \\
\text { HC: } 30 / 0\end{array}$ & $\begin{array}{l}\text { BD: } 1,5 \pm 0.2^{d} \\
H C: 2.6 \pm 0.2^{d}\end{array}$ & $P<0.001$ \\
\hline $\begin{array}{l}\text { Interleukin } 8 \\
(\mathrm{IL}-8) \mathrm{pg} / \mathrm{mL}\end{array}$ & $\begin{array}{l}\text { Isgren et al. } \\
2015 \text { (22) }\end{array}$ & $\begin{array}{l}\text { BD I: } 65 \\
\text { BD II: } 46 \\
\text { BD other: } 10 \\
\text { HC: } 71\end{array}$ & $\begin{array}{l}\text { BD: } 36.0(28.0-50.0)^{b} \\
H C: 32.0(27.0-43.0)^{b}\end{array}$ & $\begin{array}{l}\text { BD: } 47 / 74 \\
\text { HC: } 26 / 45\end{array}$ & $\begin{array}{l}\text { BD: } 33.1(27.2-41.4) \\
\text { HC: } 27.9(24.4-35.5)\end{array}$ & $P<0.001$ \\
\hline Gamma-globulin & $\begin{array}{l}\text { Dencker et al. } \\
1968(20)\end{array}$ & $\begin{array}{l}\text { Mania: } 11 \\
\text { HC: } 20\end{array}$ & $\begin{array}{l}\text { Mania: } 35-44^{e} \\
\text { HC: } 27\end{array}$ & $\begin{array}{l}\text { Mania: NA } \\
\text { HC:12/8 }\end{array}$ & $\begin{array}{l}\text { Electrophoresis Apar gel: } \\
\text { Mania: } 5 / 11 \mathrm{HC}: 0 / 20 \\
\text { Immunoelectrophoresis: } \\
\text { Mania: } 2 / 11 \mathrm{HC}: 0 / 20\end{array}$ & NA \\
\hline $\begin{array}{l}\text { Variable alter- } \\
\text { native sliced } \\
\text { exon immune- } \\
\text { reactive protein } \\
\text { (N-CAM VASE) }\end{array}$ & $\begin{array}{l}\text { Vawter et al. } \\
2000(24)\end{array}$ & $\begin{array}{l}\text { BD I: } 7 \\
\text { BD II: } 9 \\
\text { HC: } 37\end{array}$ & $\begin{array}{l}\text { BD I: } 43.1 \pm 5.0^{d} \\
\text { BD II: } 33.4 \pm 3.0^{d} \\
\text { HC: } 33.4 \pm 1.9^{d}\end{array}$ & $\begin{array}{l}\text { BD I: } 3 / 4 \\
\text { BD II: } 6 / 3 \\
\text { HC: } 24 / 13\end{array}$ & No difference between $\mathrm{BD} / \mathrm{HC}$ & NS \\
\hline $\begin{array}{l}\text { Neural cell } \\
\text { Adhesion } \\
\text { molecule } \\
\text { (N-CAM) } \mathrm{ng} / \mathrm{ml}\end{array}$ & $\begin{array}{l}\text { Poltorak el al. } \\
1996 \text { (19) }\end{array}$ & $\begin{array}{l}\text { BD I: } 16 \\
\text { BD II: } 12 \\
\text { HC: } 13\end{array}$ & $\begin{array}{l}\text { BD I: } 39.40 \pm 10.11 \\
\text { BD II: } 35.55 \pm 10.92 \\
\text { HC: } 30.85 \pm 9.07\end{array}$ & $\begin{array}{l}\text { BD I: NA } \\
\text { BD II: NA } \\
\text { HC: } 10 / 3\end{array}$ & $\begin{array}{l}\text { BD I: } 175 \pm 25 \\
\text { BD II: } 150 \pm 30 \\
\text { HC: } 125 \pm 15\end{array}$ & $\begin{array}{l}\text { BDI/HC: } \\
\text { P<0.05 } \\
\text { BDII/HC: } \\
\text { NS }\end{array}$ \\
\hline & $\begin{array}{l}\text { Hidese et al. } \\
2017(25)\end{array}$ & $\begin{array}{l}\text { BD: } 57 \\
\text { HC: } 111\end{array}$ & $\begin{array}{l}\text { BD: } 43.1 \pm 11.6 \\
\text { HC: } 42.5 \pm 15.4\end{array}$ & $\begin{array}{l}\text { BD: } 30 / 27 \\
\text { HC: } 64 / 47\end{array}$ & $\begin{array}{l}\text { BD: } 215 \pm 82.9 \\
\text { HC: } 247.2 \pm 78.5\end{array}$ & $P=0.039$ \\
\hline
\end{tabular}




\begin{tabular}{|c|c|c|c|c|c|c|}
\hline Monocyte & Jakobsson et al. & BD I: 62 & BD: $36(28-50)^{b}$ & BD: $50 / 75$ & BD: 493 (417-602) & $P=0.004$ \\
\hline $\begin{array}{l}\text { Chemoattractant } \\
\text { protein } 1 \\
(\mathrm{MCP}-1) \mathrm{pg} / \mathrm{ml}\end{array}$ & $2015(23)$ & $\begin{array}{l}\text { BD II: } 43 \\
\text { BD NOS: } 20 \\
\text { HC: } 71\end{array}$ & HC: $34(27-46)^{b}$ & HC: NA & HC: 440 (377-521) & \\
\hline $\begin{array}{l}\text { Chitinase-3-like } \\
\text { protein } 1 \\
(\mathrm{YKL}-40) \mathrm{ng} / \mathrm{ml}\end{array}$ & $\begin{array}{l}\text { Jakobsson et al. } \\
2015 \text { (23) }\end{array}$ & $\begin{array}{l}\text { BD I: } 62 \\
\text { BD II: } 43 \\
\text { BD NOS: } 20 \\
\text { HC: } 87\end{array}$ & $\begin{array}{l}\text { BD: } 36(28-50) \\
H C: 34(27-46)\end{array}$ & $\begin{array}{l}\text { BD: } 50 / 75 \\
\text { HC: } 39 / 48\end{array}$ & $\begin{array}{l}\text { BD: } 80.0(55.9-107.7) \\
H C: 440(377-521)\end{array}$ & $P=0.014$ \\
\hline IgG & $\begin{array}{l}\text { Poltorak el al. } \\
1996 \text { (19) }\end{array}$ & $\begin{array}{l}\text { BD I: } 16 \\
\text { BD II: } 12 \\
\text { HC: } 13\end{array}$ & $\begin{array}{l}\text { BD I: } 39.40 \pm 10.11 \\
\text { BD II: } 35.55 \pm 10.92 \\
\text { HC: } 30.85 \pm 9.07\end{array}$ & $\begin{array}{l}\text { BD I: NA } \\
\text { BD II: NA } \\
\text { HC: } 10 / 3\end{array}$ & NA & $P>0.9$ \\
\hline $\begin{array}{l}\text { Soluble cluster } \\
\text { of differen- } \\
\text { tiation } 14 \\
(\mathrm{sCD} 14) \mathrm{ng} / \mathrm{ml}\end{array}$ & $\begin{array}{l}\text { Jakobsson et al. } \\
2015 \text { (23) }\end{array}$ & $\begin{array}{l}\text { BD I: } 62 \\
\text { BD II: } 43 \\
\text { BD NOS: } 20 \\
\text { HC: } 87\end{array}$ & $\begin{array}{l}\text { BD: } 36(28-50) \\
\text { HC: } 34(27-46)\end{array}$ & $\begin{array}{l}\text { BD: } 50 / 75 \\
\text { HC: } 39 / 48\end{array}$ & $\begin{array}{l}\text { BD: } 49.5(33.5-69.6) \\
H C: 43.3(29.0-55.4)\end{array}$ & $P=0.19$ \\
\hline $\begin{array}{l}\text { Tissue inhibitor } \\
\text { of metallo- } \\
\text { Proteinase-1 } \\
\text { (TIMP-1) ng/ml }\end{array}$ & $\begin{array}{l}\text { Jakobsson et al. } \\
2015 \text { (23) }\end{array}$ & $\begin{array}{l}\text { BD I: } 62 \\
\text { BD II: } 43 \\
\text { BD NOS: } 20 \\
\text { HC: } 87\end{array}$ & $\begin{array}{l}\text { BD: } 36(28-50)^{b} \\
H C: 34(27-46)^{b}\end{array}$ & $\begin{array}{l}\text { BD: } 50 / 75 \\
\text { HC: } 39 / 48\end{array}$ & $\begin{array}{l}\text { BD: } 33.9(27.8-39.7) \\
H C: 32.0(28.4-36.8)\end{array}$ & $P=0.19$ \\
\hline $\begin{array}{l}\text { Tissue inhibitors } \\
\text { of metallo- } \\
\text { proteinase-2 } \\
\text { (TIMP-2) ng/ml }\end{array}$ & $\begin{array}{l}\text { Jakobsson et al. } \\
2015 \text { (23) }\end{array}$ & $\begin{array}{l}\text { BD I: } 62 \\
\text { BD II: } 43 \\
\text { BD NOS: } 20 \\
\text { HC: } 87\end{array}$ & $\begin{array}{l}\text { BD: } 36(28-50)^{b} \\
H C: 34(27-46)^{b}\end{array}$ & $\begin{array}{l}\text { BD: } 50 / 75 \\
H C: 39 / 48\end{array}$ & $\begin{array}{l}\text { BD: } 65.6 \text { (56.1-76.0) } \\
\text { HC: } 60.9 \text { (51.5-74.3) }\end{array}$ & $P=0.13$ \\
\hline
\end{tabular}

HC: Healthy control, BD: Bipolar disorder patients, Nsu: No suicidality, Su: Suicidality, NS: Non significant, NA: Not applicable.

a: Median \pm SD, ${ }^{b}:$ Median (interquartile range), ${ }^{c}$ : Range, ${ }^{d}$ : Standard error of the mean. 


\begin{tabular}{|c|c|c|c|c|c|c|}
\hline HORMONES & Study & Number & Age $^{a}$ & $\operatorname{Sex}(m / f)$ & Biomarker levels ${ }^{a}$ & $P$ value \\
\hline $\begin{array}{l}\text { Adreno- } \\
\text { Corticotropin } \\
(\mathrm{ACTH}) \mathrm{pg} / \mathrm{ml}\end{array}$ & $\begin{array}{l}\text { Berrettini et al. } \\
1986(14)\end{array}$ & $\begin{array}{l}\text { BD, nsu: } 20 \\
\text { BD, su: } 6 \\
\text { HC: } 30\end{array}$ & NA & NA & $\begin{array}{l}\text { BD, nsu: } 20.7 \pm 5.7 \\
\text { BD, su: } 24.3 \pm 5.8 \\
\text { HC: } 22.8 \pm 5.8\end{array}$ & NS \\
\hline $\begin{array}{l}\text { Alfa- melanocyte } \\
\text { Stimulating } \\
\text { hormone } \\
(\alpha-\mathrm{MSH}) \mathrm{pg} / \mathrm{ml}\end{array}$ & $\begin{array}{l}\text { Berrettini et al. } \\
1986(14)\end{array}$ & $\begin{array}{l}\text { BD, nsu: } 20 \\
\text { BD, su: } 6 \\
\text { HC: } 30\end{array}$ & NA & NA & $\begin{array}{l}\text { BD, nsu: } 22.2 \pm 1.9 \\
\text { BD, su: } 21.5 \pm 4.7 \\
\text { HC: } 22.1 \pm 2.6\end{array}$ & NS \\
\hline $\begin{array}{l}\text { Atrial natriuretic } \\
\text { factor } \\
\text { (ANF) pg/ml }\end{array}$ & $\begin{array}{l}\text { Berrettini et al. } \\
1986(14)\end{array}$ & $\begin{array}{l}\text { BD, nsu: } 20 \\
\text { BD, su: } 6 \\
\text { HC: } 30\end{array}$ & NA & NA & $\begin{array}{l}\text { BD, nsu: } 15.4 \pm 5.7 \\
\text { BD, su: } 22.0 \pm 3.9 \\
\text { HC: } 15.1 \pm 2.9\end{array}$ & NS \\
\hline $\begin{array}{l}\text { Calcitonin } \\
\mathrm{pg} / \mathrm{ml}\end{array}$ & $\begin{array}{l}\text { Berrettini et al. } \\
1986(14)\end{array}$ & $\begin{array}{l}\text { BD, nsu: } 20 \\
\text { BD, su: } 6 \\
\text { HC: } 30\end{array}$ & NA & NA & $\begin{array}{l}\text { BD, nsu: } 77.3 \pm 17.2 \\
\text { BD, su: } 79.1 \pm 14.2 \\
\text { HC: } 77.6 \pm 17.2\end{array}$ & NS \\
\hline $\begin{array}{l}\text { Corticotropin } \\
\text { releasing factor } \\
(\mathrm{CRF}) \mathrm{pg} / \mathrm{ml}\end{array}$ & $\begin{array}{l}\text { Berrettini et al. } \\
1986(14)\end{array}$ & $\begin{array}{l}\text { BD, nsu: } 20 \\
\text { BD, su: } 6 \\
\text { HC: } 30\end{array}$ & NA & NA & $\begin{array}{l}\text { BD, nsu: } 30.2 \pm 11.3 \\
\text { BD, su: } 28.2 \pm 21.3 \\
\text { HC: } 33.0 \pm 11.9\end{array}$ & NS \\
\hline $\begin{array}{l}\text { Cortisol } \\
\mathrm{ng} / \mathrm{ml}\end{array}$ & $\begin{array}{l}\text { Gerner et al. } \\
1983(26)\end{array}$ & $\begin{array}{l}\text { Mania: } 10 \\
\text { HC: } 22\end{array}$ & NA & NA & $\begin{array}{l}\text { Mania: } 8.5 \pm 0.6^{d} \\
H C: 6.62 \pm 0.42\end{array}$ & $\begin{array}{l}\text { Mania/HC: } \\
\mathbf{P}<0.05\end{array}$ \\
\hline $\begin{array}{l}\text { Growth hormone } \\
\text { releasing factor } \\
(\mathrm{GHRF}) \mathrm{pg} / \mathrm{ml}\end{array}$ & $\begin{array}{l}\text { Berrettini et al. } \\
1987 \text { (27) }\end{array}$ & $\begin{array}{l}\text { BD: } 34 \\
\text { HC: } 30\end{array}$ & $\begin{array}{l}\text { BD: } 36 \pm 10 \\
\mathrm{HC}: 32 \pm 13\end{array}$ & $\begin{array}{l}\text { BD: } 10 / 14 \\
H C: 20 / 17\end{array}$ & $\begin{array}{l}\mathrm{BD}, \text { no } \mathrm{Li}^{+}: \\
23.12 \pm 7.8 \\
\mathrm{BD}, \mathrm{Li}^{+}: 23.6 \pm 6.9 \\
\mathrm{HC}: 23.4 \pm 7.2\end{array}$ & NS \\
\hline $\begin{array}{l}\text { Melatonin } \\
\mathrm{pg} / \mathrm{ml}\end{array}$ & $\begin{array}{l}\text { Bumb et al. } \\
2016(28)\end{array}$ & $\begin{array}{l}\text { BD: } 24 \\
H C: 13\end{array}$ & NA & NA & $\begin{array}{l}\text { BD: } 8.5 \pm 2.9 \\
\text { HC: } 10.6 \pm 7.5\end{array}$ & $P<0.001$ \\
\hline $\begin{array}{l}\text { Norepinephrine } \\
(\mathrm{NE}) \mathrm{pmol} / \mathrm{ml}\end{array}$ & $\begin{array}{l}\text { Berrettini et al. } \\
1986(14)\end{array}$ & $\begin{array}{l}\text { BD, nsu: } 20 \\
\text { BD, su: } 6 \\
\text { HC: } 30\end{array}$ & NA & NA & $\begin{array}{l}\text { BD, nsu: } 0.52 \pm 0.29 \\
\text { BD, su: } 0.46 \pm 0.23 \\
\text { HC: } 0.40 \pm 0.19\end{array}$ & NS \\
\hline $\begin{array}{l}\text { Pregnenolone } \\
\mathrm{ng} / \mathrm{ml}\end{array}$ & $\begin{array}{l}\text { George et al. } \\
1994(31)\end{array}$ & $\begin{array}{l}\text { BD I: } 11 \\
\text { BD II: } 11\end{array}$ & $\begin{array}{l}\text { BD I: } 38.9 \pm 9.9 \\
\text { BD II: } 43.4 \pm 8.9\end{array}$ & $\begin{array}{l}\text { BD I: } 4 / 7 \\
\text { BD II: } 5 / 6\end{array}$ & $\begin{array}{l}\text { BD I: } 0.16 \\
\text { BD II: } 0.27\end{array}$ & $P<0.01$ \\
\hline
\end{tabular}




\begin{tabular}{|c|c|c|c|c|c|c|}
\hline & & HC: 10 & $\mathrm{HC}: 25.3 \pm 4.8$ & HC: $5 / 5$ & HC: 0.35 & \\
\hline $\begin{array}{l}\text { Progesterone } \\
\mathrm{ng} / \mathrm{ml}\end{array}$ & $\begin{array}{l}\text { George et al. } \\
1994(31)\end{array}$ & $\begin{array}{l}\text { BD I: } 11 \\
\text { BD II: } 11 \\
\text { HC: } 10\end{array}$ & $\begin{array}{l}\text { BD I: } 38.9 \pm 9.9 \\
\text { BD II: } 43.4 \pm 8.9 \\
\text { HC: } 25.3 \pm 4.8\end{array}$ & $\begin{array}{l}\text { BD I: } 4 / 7 \\
\text { BD II: } 5 / 6 \\
\text { HC: } 5 / 5\end{array}$ & $\begin{array}{l}\text { BD I: NA } \\
\text { BD II: NA } \\
\text { HC: NA }\end{array}$ & NS \\
\hline $\begin{array}{l}\text { Thyrotropin- } \\
\text { releasing } \\
\text { hormone } \\
(\mathrm{TRH}) \mathrm{pg} / \mathrm{ml}\end{array}$ & $\begin{array}{l}\text { Frye et al. } \\
1999(30)\end{array}$ & $\begin{array}{l}\text { BD: } 28 \\
\text { HC: } 34\end{array}$ & $\begin{array}{l}\text { BD: NA } \\
\mathrm{HC}: 32.5 \pm 10\end{array}$ & $\begin{array}{l}\text { BD: } 11 / 17 \\
\text { HC: } 22 / 12\end{array}$ & $\begin{array}{l}\text { BD: } 3.70 \\
\text { HC: } 3.61\end{array}$ & NS \\
\hline $\begin{array}{l}\text { Tyrosine } \\
\mathrm{ng} / \mathrm{ml}\end{array}$ & $\begin{array}{l}\text { Gerner et al. } \\
1984(13)\end{array}$ & $\begin{array}{l}\text { Mania: } 13 \\
\text { HC: } 37\end{array}$ & $\begin{array}{l}\text { Mania: } 34 \\
\text { HC: } 31\end{array}$ & NA & $\begin{array}{l}\text { Mania: } 1678 \pm 104 \\
\text { HC: } 1830 \pm 90\end{array}$ & NS \\
\hline $\begin{array}{l}\text { Vasopressin } \\
\mathrm{pg} / \mathrm{ml}\end{array}$ & $\begin{array}{l}\text { Berrettini et al. } \\
1986(14)\end{array}$ & $\begin{array}{l}\text { BD, nsu: } 20 \\
\text { BD, nu: } 6 \\
\text { HC: } 30\end{array}$ & NA & NA & $\begin{array}{l}\text { BD, nsu: } 4.5 \pm 0.9 \\
\text { BD, su: } 5.0 \pm 1.2 \\
\text { HC: } 4.0 \pm 1.0\end{array}$ & NS \\
\hline
\end{tabular}

HC: Healthy control, BD: Bipolar disorder, Nsu: No suicidality, Su: Suicidality, NS: Non significant, NA: Not applicable.

${ }^{\mathrm{a}}:$ Median \pm SD, ${ }^{\mathrm{d}}$ : Standard error 


\begin{tabular}{|c|c|c|c|c|c|c|}
\hline Biomarker & Study & Number & Age $^{b}$ & $\operatorname{Sex}(m / f)$ & Biomarker levels $^{a}$ & P value \\
\hline \multicolumn{7}{|l|}{ NEUROPEPTIDES } \\
\hline Amyloid $\beta 1-42$ & Jakobsson et al. & BD: 139 & BD: $36(28-50)$ & BD: $55 / 84$ & BD: $257 \pm 58$ & $P=0.453$ \\
\hline$(A \beta I-42) \mathrm{pg} / \mathrm{ml}$ & $2013(32)$ & HC: 71 & HC: 32 (27-43) & HC: $26 / 45$ & HC: $255 \pm 54$ & \\
\hline Amyloid $\beta 38$ & Jakobsson et al. & BD: 139 & BD: 36 (28-50) & BD: $55 / 84$ & BD: $1203 \pm 488$ & $P=0.557$ \\
\hline$(A \beta-38) \mathrm{pg} / \mathrm{ml}$ & $2013(32)$ & HC: 71 & HC: 32 (27-43) & HC: $26 / 45$ & HC: $1254 \pm 463$ & \\
\hline Amyloid $\beta 40$ & Jakobsson et al. & BD: 139 & BD: 36 (28-50) & BD: $55 / 84$ & BD: $7848 \pm 2301$ & $P=0.402$ \\
\hline$(A \beta-40) \mathrm{pg} / \mathrm{ml}$ & $2013(32)$ & HC: 71 & HC: 32 (27-43) & HC: $26 / 45$ & HC: $8280 \pm 2712$ & \\
\hline Amyloid $\beta 42$ & Jakobsson et al. & BD: 139 & BD: 36 (28-50) & BD: $55 / 84$ & BD: $935 \pm 373$ & $P=0.607$ \\
\hline \multirow[t]{3}{*}{$(\mathrm{A} \beta-42) \mathrm{pg} / \mathrm{ml}$} & $2013(32)$ & HC: 71 & HC: 32 (27-43) & HC: $26 / 45$ & HC: $920 \pm 336$ & \\
\hline & Forlenza et al. & BD: 16 & BD: $70.5 \pm 4.9^{\mathrm{a}}$ & BD: $4 / 12$ & BD: $384.7 \pm 141.3$ & $P=0.007$ \\
\hline & $2016(4)$ & HC: 25 & $\mathrm{HC}: 72.0 \pm 4.4^{\mathrm{a}}$ & HC: $5 / 20$ & HC: $464.4 \pm 154.1$ & \\
\hline Amyloid Precursor & Jakobsson et al. & BD: 139 & BD: 36 (28-50) & BD: $55 / 84$ & BD: $732 \pm 323$ & $P=0.004$ \\
\hline $\begin{array}{l}\text { Protein- } \alpha \\
(\text { APP- } \alpha) \mathrm{ng} / \mathrm{ml}\end{array}$ & $2013(32)$ & HC: 71 & HC: 32 (27-43) & HC: $26 / 45$ & HC: $864 \pm 279$ & \\
\hline Amyloid Precursor & Jakobsson et al. & BD: 139 & BD: 36 (28-50) & BD: $55 / 84$ & BD: $308 \pm 170$ & $P=0.056$ \\
\hline $\begin{array}{l}\text { Protein } \beta \\
(\text { APP- } \beta) \mathrm{ng} / \mathrm{ml}\end{array}$ & $2013(32)$ & HC: 71 & HC: 32 (27-43) & HC: $26 / 45$ & HC: $356 \pm 152$ & \\
\hline Amyloid $\beta$ 42/ & Jakobsson et al. & BD: 139 & BD: 36 (28-50) & BD: $55 / 84$ & BD: $0.117 \pm 0.020$ & $P=0.029$ \\
\hline $\begin{array}{l}\text { Amyloid } \beta 40 \\
\text { (Aß-42/ A } 3-40)\end{array}$ & $2013(32)$ & HC: 71 & HC: 32 (27-43) & HC: $26 / 45$ & HC: $0.111 \pm 0.017$ & \\
\hline Amyloid $\beta$ 42/ & Jakobsson et al. & BD: 139 & BD: $36(28-50)$ & BD: $55 / 84$ & BD: $0.789 \pm 0.109$ & $P=0.002$ \\
\hline $\begin{array}{l}\text { Amyloid } \beta 38 \\
(A \beta-42 / A \beta-38)\end{array}$ & $2013(32)$ & HC: 71 & HC: 32 (27-43) & HC: $26 / 45$ & HC: $0.741 \pm 0.097$ & \\
\hline Amyloid $\beta$ 42/ & Forlenza et al. & BD: 16 & BD: $70.5 \pm 4.9^{a}$ & BD: 4/12 & BD: $14.0 \pm 7.7$ & $P<0.0001$ \\
\hline T-tau $\mathrm{pg} / \mathrm{ml}$ & $2016(4)$ & HC: 25 & $\mathrm{HC}: 72.0 \pm 4.4^{\mathrm{a}}$ & HC: $5 / 20$ & HC: $5.5 \pm 3.1$ & \\
\hline Amyloid $\beta$ 42/ & Forlenza et al. & BD: 16 & $\mathrm{BD}: 70.5 \pm 4.9^{\mathrm{a}}$ & BD: 4/12 & BD: $35.9 \pm 25.2$ & $P=0.002$ \\
\hline P-tau $\mathrm{pg} / \mathrm{ml}$ & $2016(4)$ & HC: 25 & $\mathrm{HC}: 72.0 \pm 4.4^{\mathrm{a}}$ & HC: $5 / 20$ & HC: $39.5 \pm 15.4$ & \\
\hline $\begin{array}{l}\text { Bombesin } \\
\mathrm{fmol} / \mathrm{ml}\end{array}$ & $\begin{array}{l}\text { Gerner et al. } \\
1982(38)\end{array}$ & $\begin{array}{l}\text { Mania: } 10 \\
\text { HC: } 29\end{array}$ & NA & NA & $\begin{array}{l}\text { Mania: } 32 \\
\text { HC: } 35\end{array}$ & NS \\
\hline $\begin{array}{l}\text { Cholecystokinin } \\
\text { (CCK) fmol/ml }\end{array}$ & $\begin{array}{l}\text { Gerner et al. } \\
1982(38)\end{array}$ & $\begin{array}{l}\text { Mania: } 10 \\
\text { HC: } 29\end{array}$ & NA & NA & $\begin{array}{l}\text { Mania: } 9.5 \pm 1.5 \\
\text { HC: } 10 \pm 1.5\end{array}$ & NS \\
\hline
\end{tabular}




\begin{tabular}{|c|c|c|c|c|c|c|}
\hline $\mathrm{pmol} / \mathrm{l}$ & $\begin{array}{l}\text { Verbanck et al. } \\
1984 \text { (39) }\end{array}$ & $\begin{array}{l}\text { BD depr.: } 12 \\
\text { HC: } 51\end{array}$ & $\begin{array}{l}\text { BD: NA } \\
\text { HC: } 52\end{array}$ & $\begin{array}{l}\text { BD: NA } \\
\text { HC: } 29 / 22\end{array}$ & $\begin{array}{l}\text { BD: } 2.8 \pm 0.6 \\
\text { HC: } 5.4 \pm 0.8\end{array}$ & $P<0.05$ \\
\hline $\begin{array}{l}\text { Cromogranin II } \\
\text { (GgB) nmol// }\end{array}$ & $\begin{array}{l}\text { Jakobsson et al. } \\
2013(33)\end{array}$ & $\begin{array}{l}\text { BD I: } 76 \\
\text { BD II: } 50 \\
\text { HC: } 71\end{array}$ & $\begin{array}{l}\text { BD: } 34(28-50) \\
\text { HC: } 32(27-43)\end{array}$ & $\begin{array}{l}\text { BD: } 49 / 77 \\
\text { HC: } 26 / 45\end{array}$ & $\begin{array}{l}\text { BD I: } 19 \\
\text { BD II: } 20 \\
\text { HC: } 20\end{array}$ & $\begin{array}{l}\text { BDI/HC: } \\
P=0.07 \\
\text { BDII/ HC: } \\
P=0.95\end{array}$ \\
\hline $\begin{array}{l}\text { Diazepam } \\
\text { binding inhibitor }\end{array}$ & $\begin{array}{l}\text { George et al. } \\
1994 \text { (31) }\end{array}$ & $\begin{array}{l}\text { BD I: } 11 \\
\text { BD II: } 11 \\
\text { HC: } 10\end{array}$ & $\begin{array}{l}\text { BD I: } 38.9 \pm 9.9^{\mathrm{a}} \\
\text { BD II: } 43.4 \pm 8.9^{\mathrm{a}} \\
\text { HC: } 25.3 \pm 4.8^{\mathrm{a}}\end{array}$ & $\begin{array}{l}\text { BD I: } 4 / 7 \\
\text { BD II: } 5 / 6 \\
\text { HC: } 5 / 5\end{array}$ & $\begin{array}{l}\text { BD I: NA } \\
\text { BD II: NA } \\
\text { HC: NA }\end{array}$ & NS \\
\hline $\begin{array}{l}\text { B-endorphin } \\
\text { (BE) pmol/l }\end{array}$ & $\begin{array}{l}\text { Naber et al. } \\
1981 \text { (34) } \\
\text { Berrettini et al. } \\
1986 \text { (14) }\end{array}$ & $\begin{array}{l}\text { Mania: } 12 \\
\text { HC: } 33 \\
\text { BD, nsu: } 20 \\
\text { BD, su: } 6 \\
\text { HC: } 30\end{array}$ & $\begin{array}{l}\text { Mania: } 34 \pm 13^{\mathrm{a}} \\
\mathrm{HC}: 31 \pm 13^{\mathrm{a}} \\
\text { NA }\end{array}$ & $\begin{array}{l}\text { Mania: } 3 / 9 \\
\text { HC: } 21 / 12 \\
\text { NA }\end{array}$ & $\begin{array}{l}\text { Mania: } 58 \pm 27 \\
\text { HC: } 59 \pm 39 \\
\text { BD, nsu } 37.0 \pm 5.8 \\
\text { BD, su: } 41.3 \pm 12.6 \\
\text { HC: } 40.2 \pm 6.9\end{array}$ & $\begin{array}{l}\text { NS } \\
\text { NS }\end{array}$ \\
\hline $\begin{array}{l}\text { Beta-lipoprotein } \\
\text { (B-LPH) pg/ml }\end{array}$ & $\begin{array}{l}\text { Berrettini et al. } \\
1986(14)\end{array}$ & $\begin{array}{l}\text { BD, nsu: } 20 \\
\text { BD, su: } 6 \\
\text { HC: } 30\end{array}$ & NA & NA & $\begin{array}{l}\text { BD, nsu: } 82.9 \pm 23.9 \\
\text { BD, su: } 61.8 \pm 8.3 \\
\text { HC: } 73.1 \pm 20.1\end{array}$ & NS \\
\hline $\begin{array}{l}\text { Calmodulin } \\
\mathrm{pg} / \mathrm{ml}\end{array}$ & $\begin{array}{l}\text { Berrettini et al. } \\
1986(14)\end{array}$ & $\begin{array}{l}\text { BD, nsu: } 20 \\
\text { BD, su: } 6 \\
\text { HC: } 30\end{array}$ & NA & NA & $\begin{array}{l}\text { BD, nsu: } 28.4 \pm 20.4 \\
\text { BD, su: } 21.7 \pm 18.6 \\
\text { HC: } 29.5 \pm 15.9\end{array}$ & NS \\
\hline \multirow{3}{*}{$\begin{array}{l}\text { Gamma amino } \\
\text { butyric acid } \\
\text { (GABA) pmol/ml }\end{array}$} & $\begin{array}{l}\text { Gerner et al. } \\
1984 \text { (13) }\end{array}$ & $\begin{array}{l}\text { Mania: } 12 \\
\text { HC: } 36\end{array}$ & $\begin{array}{l}\text { Mania: } 34^{\mathrm{a}} \\
\text { HC: } 31^{\mathrm{a}}\end{array}$ & NA & $\begin{array}{l}\text { Mania: } 171 \pm 12.4 \\
\text { HC: } 190 \pm 5.2\end{array}$ & NS \\
\hline & $\begin{array}{l}\text { Berrettini et al. } \\
1986(14)\end{array}$ & $\begin{array}{l}\text { BD, nsu: } 20 \\
\text { BD, su: } 6 \\
\text { HC: } 30\end{array}$ & NA & NA & $\begin{array}{l}\text { BD, nsu: } 135 \pm 23 \\
\text { BD, su: } 113 \pm 46 \\
\text { HC: } 127 \pm 44\end{array}$ & NS \\
\hline & $\begin{array}{l}\text { Mann et al. } \\
2014 \text { (15) }\end{array}$ & $\begin{array}{l}\text { BD: } 37 \\
\text { HC: } 38\end{array}$ & $\begin{array}{l}\text { BD: NA } \\
\text { HC: } 34.8 \pm 13.3^{\mathrm{a}}\end{array}$ & $\begin{array}{l}\text { BD: NA } \\
\text { HC: } 22 / 16\end{array}$ & $\begin{array}{l}\text { BD: } 18.7 \pm 12.3 \\
\text { HC: } 17.4 \pm 7.6\end{array}$ & $P>0.05$ \\
\hline $\begin{array}{l}\text { Glutamate } \\
\mu \mathrm{M}\end{array}$ & $\begin{array}{l}\text { Palsson et al. } \\
2015 \text { (41) }\end{array}$ & $\begin{array}{l}\text { BD: } 132 \\
\text { HC: } 87\end{array}$ & $\begin{array}{l}\text { BD all: } 26(28-48) \\
\text { HC: } 35 \text { (27-45) }\end{array}$ & NA & $\begin{array}{l}\text { BD: } 0.75 \pm 0.38 \\
\text { HC: } 0.68 \pm 0.19\end{array}$ & $P=0.15$ \\
\hline $\begin{array}{l}\text { Glutamine } \\
\mu \mathrm{M}\end{array}$ & $\begin{array}{l}\text { Palsson et al. } \\
2015 \text { (41) }\end{array}$ & $\begin{array}{l}\text { BD: } 132 \\
\text { HC: } 87\end{array}$ & $\begin{array}{l}\text { BD all: } 26 \text { (28-48) } \\
\text { HC: } 35 \text { (27-45) }\end{array}$ & NA & $\begin{array}{l}\text { BD: } 516 \pm 82.5 \\
\text { HC: } 499 \pm 65.6\end{array}$ & $P<0.026$ \\
\hline Glycine & Palsson et al. & BD: 132 & BD all: 26 (28-48) & NA & BD: $8.2 \pm 4.4$ & $P=0.36$ \\
\hline$\mu \mathrm{M}$ & $2015(41)$ & HC: 87 & HC: 35 (27-45) & & HC: $7.6 \pm 3.5$ & \\
\hline Heart-type fatty & Jakobsson et al. & BD: 133 & BD: 35 (28-50) & BD: $52 / 81$ & BD: $453 \pm 17$ & $P=0.11$ \\
\hline
\end{tabular}




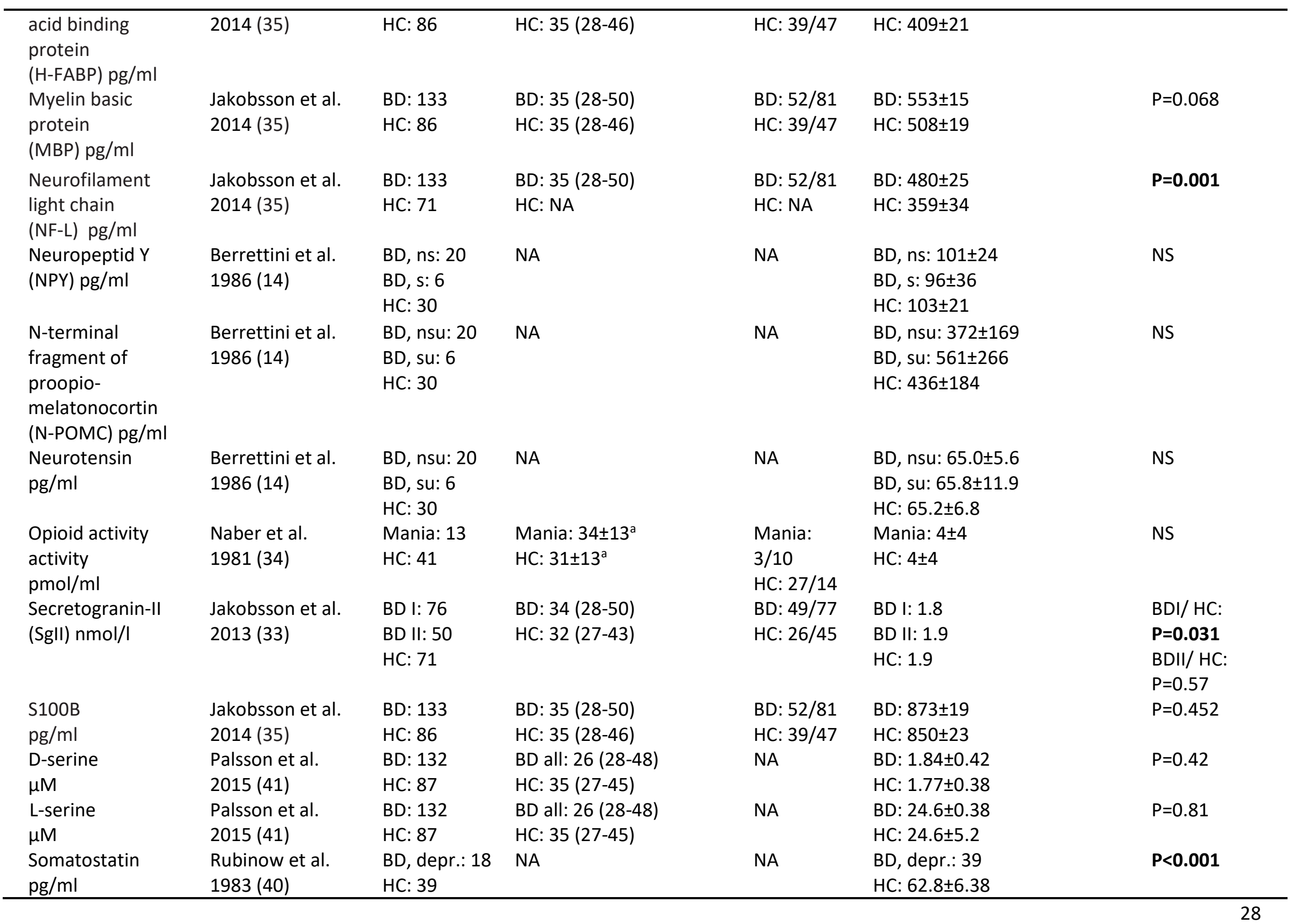




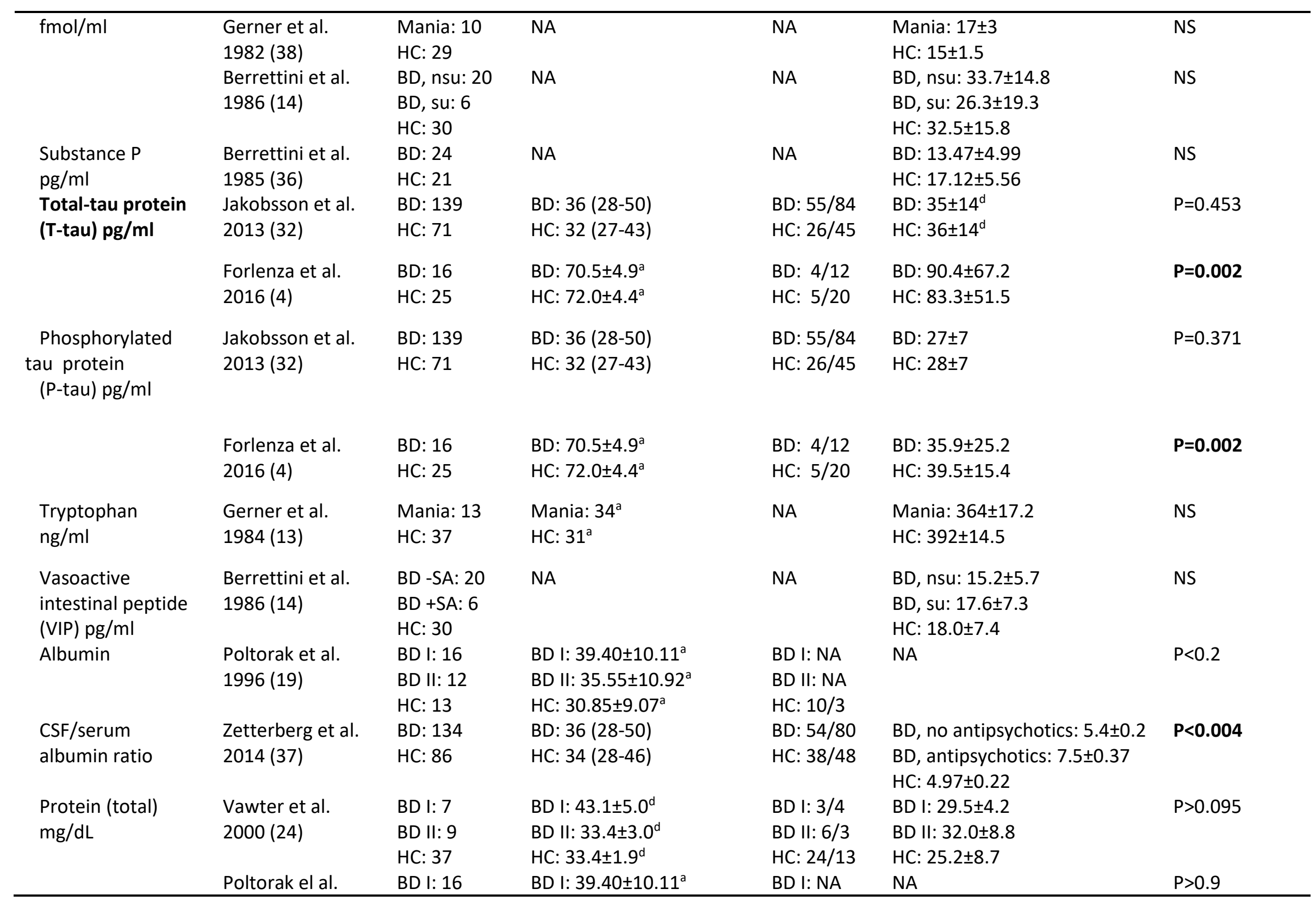


HC: Healthy control, Nsu: No suicidality, Su: Suicidality, NS: Non significant, NA: Not applicable.

${ }^{a}$ : Median $\pm S D,{ }^{b}$ : Median (interquartile range), ${ }^{d}$ : Standard error of the mean 


\begin{tabular}{|c|c|c|c|c|c|c|}
\hline OTHER Biomarkers & Study & Number & $\mathrm{Age}^{\mathrm{a}}$ & $\operatorname{Sex}(m / f)$ & Biomarker levels $^{a}$ & $P$ value \\
\hline \multirow[t]{2}{*}{ Glucose } & Regenold et al. & BD: 10 & BD: $38.7 \pm 12.4$ & BD: $4 / 6$ & BD: $60.0 \pm 7.6$ & NS \\
\hline & $2000(43)$ & HC: 10 & $\mathrm{HC}: 41.1 \pm 8.2$ & $\mathrm{HC}: 6 / 4$ & $\mathrm{HC}: 58.9 \pm 4.2$ & \\
\hline Sorbitol & Regenold et al. & BD: 10 & BD: $38.7 \pm 12.4$ & BD: $4 / 6$ & BD: $22.9 \pm 4.6$ & $P=0.0002$ \\
\hline $\mu$ moles/l & $2000(43)$ & HC: 10 & $\mathrm{HC}: 41.1 \pm 8.2$ & HC: $6 / 4$ & HC: $15.6 \pm 1.9$ & \\
\hline \multirow[t]{3}{*}{ Magnesium } & George et al. & BD I: 76 & BD I: $41.4 \pm 13.8$ & BD I: 40/36 & BD I: $1.12 \pm 0.01$ & NS \\
\hline & 1994 (29) & BD II: 54 & 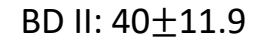 & BD II: 33/21 & BD II: 1.12士0.11 & \\
\hline & & HC: 59 & HC: $30.5 \pm 12.5$ & HC: $22 / 37$ & HC: $1.13 \pm 0.07$ & \\
\hline
\end{tabular}

HC: Healthy control, Nsu: No suicidality, Su: Suicidality, NS: Non significant, NA: Not applicable, ${ }^{a}$ : Median \pm SD 


\begin{tabular}{|c|c|c|c|c|c|c|}
\hline Biomarker & Study & Number & Age $^{b}$ & $\operatorname{Sex}(m / f)$ & Biomarker levels $^{a}$ & $P$ value \\
\hline \multicolumn{7}{|l|}{ METABOLOMICS } \\
\hline $\begin{array}{l}\text { cyclic AMP } \\
\text { (cAMP) } \mu \mathrm{M}\end{array}$ & $\begin{array}{l}\text { Yoshimi et al. } \\
2016(42)\end{array}$ & $\begin{array}{l}\text { BD: } 54 \\
\text { HC: } 39\end{array}$ & $\begin{array}{l}\text { BD: } 41(32-52) \\
\text { HC: } 36(30-47)\end{array}$ & All males & $\begin{array}{l}\text { BD: } 0.03 \pm 8.13 E-03 \\
H C: 0.03 \pm 7.23 E-03\end{array}$ & $P=0.533$ \\
\hline $\begin{array}{l}\text { cyclic GMP } \\
\text { (cGMP) } \mu \mathrm{M}\end{array}$ & $\begin{array}{l}\text { Yoshimi et al. } \\
2016(42)\end{array}$ & $\begin{array}{l}\text { BD: } 44 \\
\text { HC: } 34\end{array}$ & NA & All males & $\begin{array}{r}\text { BD: } 7.54 \mathrm{E}-03 \pm 3.35 \mathrm{E}-03 \\
\mathrm{HC}: 7.15 \mathrm{E}-03 \pm 2.99 \mathrm{E}-3\end{array}$ & $P=0.594$ \\
\hline $\begin{array}{l}\text { Xanthine } \\
\mu \mathrm{M}\end{array}$ & $\begin{array}{l}\text { Yoshimi et al. } \\
2016(42)\end{array}$ & $\begin{array}{l}\text { BD: } 54 \\
\text { HC: } 40\end{array}$ & $\begin{array}{l}\text { BD: } 41(32-52) \\
\text { HC: } 36(30-47)\end{array}$ & All males & $\begin{array}{l}\text { BD: } 2.1 \pm 0.6 \\
\text { HC: } 2.0 \pm 0.4\end{array}$ & $P=0.377$ \\
\hline $\begin{array}{l}\text { ADP-ribose } \\
\mu \mathrm{M}\end{array}$ & $\begin{array}{l}\text { Yoshimi et al. } \\
2016(42)\end{array}$ & $\begin{array}{l}\text { BD: } 11 \\
\text { HC: } 10\end{array}$ & NA & All males & $\begin{array}{l}\text { BD: } 4.81 \mathrm{E}-03 \pm 8.27 \mathrm{E}-04 \\
\mathrm{HC}: 4.41 \mathrm{E}-03 \pm 3.09 \mathrm{E}-04\end{array}$ & $P=0.154$ \\
\hline $\begin{array}{l}\text { Uric acid } \\
\mu \mathrm{M}\end{array}$ & $\begin{array}{l}\text { Yoshimi et al. } \\
2016(42)\end{array}$ & $\begin{array}{l}\text { BD: } 54 \\
\text { HC: } 40\end{array}$ & $\begin{array}{l}\text { BD: } 41(32-52) \\
\text { HC: } 36 \text { (30-47) }\end{array}$ & All males & $\begin{array}{l}\text { BD: } 29 \pm 11 \\
\text { HC: } 23 \pm 8.9\end{array}$ & $P=0.008$ \\
\hline $\begin{array}{l}\text { Nicotinamide } \\
\text { adenine } \\
\text { dinucleaotide } \\
\text { phosphate } \\
\text { (oxidized form) } \\
\text { (NADP+) }\end{array}$ & $\begin{array}{l}\text { Yoshimi et al. } \\
2016(42)\end{array}$ & $\begin{array}{l}\text { BD: } 14 \\
\text { HC: } 11\end{array}$ & NA & All males & $\begin{array}{l}\text { BD: } 0.02 \pm 2.24 E-03 \\
H C: 0.02 \pm 3.33 E-03\end{array}$ & $P=0.978$ \\
\hline $\begin{array}{l}\text { Fructose 6- } \\
\text { phosphate } \\
\mu \mathrm{M}\end{array}$ & $\begin{array}{l}\text { Yoshimi et al. } \\
2016(42)\end{array}$ & $\begin{array}{l}\text { BD: } 37 \\
\text { HC: } 28\end{array}$ & NA & All males & $\begin{array}{l}\mathrm{BD}: 0.1 \pm 0.02 \\
\mathrm{HC}: 0.1 \pm 0.03\end{array}$ & $P=0.049$ \\
\hline $\begin{array}{l}\text { Acetyl CoA } \\
\mu \mathrm{M}\end{array}$ & $\begin{array}{l}\text { Yoshimi et al. } \\
2016(42)\end{array}$ & $\begin{array}{l}\text { BD: } 13 \\
\text { HC: } 15\end{array}$ & NA & All males & $\begin{array}{l}\text { BD: } 0.01 \pm 2.07 E-03 \\
\text { HC: } 0.01 \pm 3.14 E-03\end{array}$ & $P=0.996$ \\
\hline $\begin{array}{l}\text { Ribose 5- } \\
\text { phosphate } \\
\mu \mathrm{M}\end{array}$ & $\begin{array}{l}\text { Yoshimi et al. } \\
2016(42)\end{array}$ & $\begin{array}{l}\text { BD: } 23 \\
\text { HC: } 11\end{array}$ & NA & All males & $\begin{array}{c}\text { BD: } 0.04 \pm 0.02 \\
H C: 0.03 \pm 07.95 E-03\end{array}$ & $P=0.013$ \\
\hline $\begin{array}{l}\text { Glycerol 3- } \\
\text { phosphate } \\
\mu \mathrm{M}\end{array}$ & $\begin{array}{l}\text { Yoshimi et al. } \\
2016(42)\end{array}$ & $\begin{array}{l}\text { BD: } 54 \\
\text { HC: } 40\end{array}$ & $\begin{array}{l}\text { BD: } 41(32-52) \\
H C: 36(30-47)\end{array}$ & All males & $\begin{array}{l}\text { BD: } 3.8 \pm 1.2 \\
H C: 3.74 \pm 1.1\end{array}$ & $P=0.619$ \\
\hline
\end{tabular}




\begin{tabular}{|c|c|c|c|c|c|c|}
\hline $\begin{array}{l}\text { Phosphocreatine } \\
\mu \mathrm{M}\end{array}$ & \begin{tabular}{|l} 
Yoshimi et al. \\
$2016(42)$
\end{tabular} & $\begin{array}{l}\text { BD: } 54 \\
\text { HC: } 40\end{array}$ & $\begin{array}{l}\text { BD: } 41 \text { (32-52) } \\
\text { HC: } 36 \text { (30-47) }\end{array}$ & All males & $\begin{array}{l}\text { BD: } 1 \pm 0.4 \\
H C: 0.9 \pm 0.3\end{array}$ & $P=0.135$ \\
\hline $\begin{array}{l}\text { Xanthosine } \\
\text { monophosphate } \\
\text { (XMP) } \mu \mathrm{M}\end{array}$ & $\begin{array}{l}\text { Yoshimi et al. } \\
2016(42)\end{array}$ & $\begin{array}{l}\text { BD: } 11 \\
\text { HC: } 10\end{array}$ & NA & All males & $\begin{array}{l}\text { BD: } 0.03 \pm 2.78 \mathrm{E}-03 \\
\mathrm{HC}: 0.02 \pm 1.38 \mathrm{E}-03\end{array}$ & $P=0.210$ \\
\hline $\begin{array}{l}\text { Adenylosuccinic } \\
\text { acid } \\
\mu \mathrm{M}\end{array}$ & $\begin{array}{l}\text { Yoshimi et al. } \\
2016(42)\end{array}$ & $\begin{array}{l}\text { BD: } 15 \\
\mathrm{HC}: 11\end{array}$ & NA & All males & $\begin{array}{l}\mathrm{BD}: 0.03 \pm 2.85 \mathrm{E}-03 \\
\mathrm{HC}: 0.03 \pm 2.32 \mathrm{E}-03\end{array}$ & $P=0.927$ \\
\hline $\begin{array}{l}\text { 2-Oxoisovaleric } \\
\text { acid } \mu \mathrm{M}\end{array}$ & $\begin{array}{l}\text { Yoshimi et al. } \\
2016(42)\end{array}$ & $\begin{array}{l}\text { BD: } 54 \\
\text { HC: } 40\end{array}$ & $\begin{array}{l}\text { BD: } 41 \text { (32-52) } \\
\text { HC: } 36(30-47)\end{array}$ & All males & $\begin{array}{l}\text { BD: } 3.9 \pm 0.6 \\
\text { HC: } 3.6 \pm 0.5\end{array}$ & $P=0.021$ \\
\hline $\begin{array}{l}\text { Lactic acid } \\
\mu \mathrm{M}\end{array}$ & $\begin{array}{l}\text { Yoshimi et al. } \\
2016(42)\end{array}$ & $\begin{array}{l}\text { BD: } 54 \\
\text { HC: } 40\end{array}$ & $\begin{array}{l}\text { BD: } 41 \text { (32-52) } \\
\text { HC: } 36(30-47)\end{array}$ & All males & $\begin{array}{l}\text { BD: } 1.601 \pm 247 \\
\text { HC: } 1.480 \pm 171\end{array}$ & $P=0.006$ \\
\hline $\begin{array}{l}\text { Glycolic acid } \\
\mu \mathrm{M}\end{array}$ & $\begin{array}{l}\text { Yoshimi et al. } \\
2016(42)\end{array}$ & $\begin{array}{l}\text { BD: } 52 \\
\text { HC: } 40\end{array}$ & $\begin{array}{l}\text { BD: } 41 \text { (32-52) } \\
\text { HC: } 36 \text { (30-47) }\end{array}$ & All males & $\begin{array}{l}\text { BD: } 8.4 \pm 2.2 \\
\text { HC: } 8.1 \pm 2.8\end{array}$ & $P=0.467$ \\
\hline $\begin{array}{l}\text { Pyruvic acid } \\
\mu \mathrm{M}\end{array}$ & $\begin{array}{l}\text { Yoshimi et al. } \\
2016(42)\end{array}$ & $\begin{array}{l}\text { BD: } 54 \\
\text { HC: } 40\end{array}$ & $\begin{array}{l}\text { BD: } 41 \text { (32-52) } \\
\text { HC: } 36 \text { (30-47) }\end{array}$ & All males & $\begin{array}{l}\text { BD: } 21 \pm 11 \\
H C: 15 \pm 6.9\end{array}$ & $P=0.002$ \\
\hline $\begin{array}{l}\text { Succinic acid } \\
\mu \mathrm{M}\end{array}$ & \begin{tabular}{|l} 
Yoshimi et al. \\
$2016(42)$
\end{tabular} & $\begin{array}{l}\text { BD: } 53 \\
\text { HC: } 38\end{array}$ & $\begin{array}{l}\text { BD: } 41 \text { (32-52) } \\
\text { HC: } 36 \text { (30-47) }\end{array}$ & All males & $\begin{array}{l}\text { BD: } 4.0 \pm 1.3 \\
\text { HC: } 3.6 \pm 1.4\end{array}$ & $P=0.255$ \\
\hline $\begin{array}{l}\text { Citric acid } \\
\mu \mathrm{M}\end{array}$ & $\begin{array}{l}\text { Yoshimi et al. } \\
2016(42)\end{array}$ & $\begin{array}{l}\text { BD: } 54 \\
\text { HC: } 40\end{array}$ & $\begin{array}{l}\text { BD: } 41 \text { (32-52) } \\
\text { HC: } 36(30-47)\end{array}$ & All males & $\begin{array}{l}\text { BD: } 227 \pm 54 \\
\text { HC: } 180 \pm 35\end{array}$ & $P<0.0001$ \\
\hline $\begin{array}{l}\text { Isocitric acid } \\
\mu \mathrm{M}\end{array}$ & $\begin{array}{l}\text { Yoshimi et al. } \\
2016(42)\end{array}$ & $\begin{array}{l}\text { BD: } 54 \\
\text { HC: } 40\end{array}$ & $\begin{array}{l}\text { BD: } 41(32-52) \\
\text { HC: } 36(30-47)\end{array}$ & All males & $\begin{array}{l}\text { BD: } 4.8 \pm 1.1 \\
\text { HC: } 3.4 \pm 0.9\end{array}$ & $P<0.0001$ \\
\hline $\begin{array}{l}\text { cis-Aconitic acid } \\
\mu \mathrm{M}\end{array}$ & $\begin{array}{l}\text { Yoshimi et al. } \\
2016(42)\end{array}$ & $\begin{array}{l}\text { BD: } 54 \\
\text { HC: } 40\end{array}$ & $\begin{array}{l}\text { BD: } 41 \text { (32-52) } \\
\text { HC: } 36 \text { (30-47) }\end{array}$ & All males & $\begin{array}{l}\text { BD: } 1.7 \pm 0.5 \\
\text { HC: } 1.2 \pm 0.4\end{array}$ & $P<0.0001$ \\
\hline $\begin{array}{l}\text { Urea } \\
\mu \mathrm{M}\end{array}$ & $\begin{array}{l}\text { Yoshimi et al. } \\
2016(42)\end{array}$ & $\begin{array}{l}\text { BD: } 54 \\
\text { HC: } 40\end{array}$ & $\begin{array}{l}\text { BD: } 41 \text { (32-52) } \\
\text { HC: } 36 \text { (30-47) }\end{array}$ & All males & $\begin{array}{l}\text { BD: } 4392 \pm 968 \\
\text { HC: } 5035 \pm 999\end{array}$ & $P=0.002$ \\
\hline $\begin{array}{l}\text { Glycine } \\
\text { (Gly) } \mu \mathrm{M}\end{array}$ & $\begin{array}{l}\text { Yoshimi et al. } \\
2016(42)\end{array}$ & $\begin{array}{l}\text { BD: } 54 \\
\text { HC: } 40\end{array}$ & $\begin{array}{l}\text { BD: } 41 \text { (32-52) } \\
\text { HC: } 36 \text { (30-47) }\end{array}$ & All males & $\begin{array}{l}\text { BD: } 4.9 \pm 2.9 \\
\text { HC: } 4.4 \pm 1.7\end{array}$ & $P=0.323$ \\
\hline $\begin{array}{l}\text { Alanin } \\
\text { (Ala) } \mu \mathrm{M}\end{array}$ & $\begin{array}{l}\text { Yoshimi et al. } \\
2016(42)\end{array}$ & $\begin{array}{l}\text { BD: } 54 \\
\text { HC: } 40\end{array}$ & $\begin{array}{l}\text { BD: } 41 \text { (32-52) } \\
\text { HC: } 36 \text { (30-47) }\end{array}$ & All males & $\begin{array}{l}\text { BD: } 37 \pm 10 \\
H C: 32 \pm 9.8\end{array}$ & $P=0.033$ \\
\hline
\end{tabular}




\begin{tabular}{|c|c|c|c|c|c|c|}
\hline $\begin{array}{l}\text { Y-Aminobutyric } \\
\text { acid } \\
\text { (GABA) } \mu \mathrm{M}\end{array}$ & $\begin{array}{l}\text { Yoshimi et al. } \\
2016(42)\end{array}$ & $\begin{array}{l}\text { BD: } 13 \\
\text { HC: } 13\end{array}$ & NA & All males & $\begin{array}{c}\text { BD: } 0.5 \pm 0.09 \\
H C: 0.5 \pm 0.2\end{array}$ & $P=0.357$ \\
\hline $\begin{array}{l}\text { Serine } \\
\text { (Ser) } \mu \mathrm{M}\end{array}$ & $\begin{array}{l}\text { Yoshimi et al. } \\
2016(42)\end{array}$ & $\begin{array}{l}\text { BD: } 54 \\
\text { HC: } 40\end{array}$ & $\begin{array}{l}\text { BD: } 41(32-52) \\
\text { HC: } 36(30-47)\end{array}$ & All males & $\begin{array}{l}\text { BD: } 30 \pm 6.9 \\
\text { HC: } 31 \pm 4.6\end{array}$ & $P=0.663$ \\
\hline $\begin{array}{l}\text { Creatinine } \\
\mu \mathrm{M}\end{array}$ & $\begin{array}{l}\text { Yoshimi et al. } \\
2016(42)\end{array}$ & $\begin{array}{l}\text { BD: } 54 \\
\text { HC: } 40\end{array}$ & $\begin{array}{l}\text { BD: } 41(32-52) \\
\text { HC: } 36(30-47)\end{array}$ & All males & $\begin{array}{l}\text { BD: } 67 \pm 11 \\
\text { HC: } 66 \pm 12\end{array}$ & $P=0.590$ \\
\hline $\begin{array}{l}\text { Valine } \\
\text { (Val) } \mu \mathrm{M}\end{array}$ & $\begin{array}{l}\text { Yoshimi et al. } \\
2016(42)\end{array}$ & $\begin{array}{l}\text { BD: } 54 \\
\text { HC: } 40\end{array}$ & $\begin{array}{l}\text { BD: } 41(32-52) \\
\text { HC: } 36(30-47)\end{array}$ & All males & $\begin{array}{l}\text { BD: } 23 \pm 7.5 \\
\text { HC: } 22 \pm 7.7\end{array}$ & $P=0.698$ \\
\hline $\begin{array}{l}\text { Threonine } \\
\text { (Thr) } \mu \mathrm{M}\end{array}$ & $\begin{array}{l}\text { Yoshimi et al. } \\
2016(42)\end{array}$ & $\begin{array}{l}\text { BD: } 54 \\
\text { HC: } 40 \\
\end{array}$ & $\begin{array}{l}\text { BD: } 41(32-52) \\
\text { HC: } 36(30-47)\end{array}$ & All males & $\begin{array}{l}\text { BD: } 32 \pm 7.9 \\
\text { HC: } 32 \pm 7.6\end{array}$ & $P=0.998$ \\
\hline $\begin{array}{l}\text { Hydroxyproline } \\
\mu \mathrm{M}\end{array}$ & $\begin{array}{l}\text { Yoshimi et al. } \\
2016(42)\end{array}$ & $\begin{array}{l}\text { BD: } 54 \\
\text { HC: } 40\end{array}$ & $\begin{array}{l}\text { BD: } 41(32-52) \\
\text { HC: } 36 \text { (30-47) }\end{array}$ & All males & $\begin{array}{l}\text { BD: } 2.0 \pm 0.4 \\
\text { HC: } 1.9 \pm 0.3\end{array}$ & $P=0.086$ \\
\hline $\begin{array}{l}\text { Creatine } \\
\mu \mathrm{M}\end{array}$ & $\begin{array}{l}\text { Yoshimi et al. } \\
2016(42)\end{array}$ & $\begin{array}{l}\text { BD: } 54 \\
\text { HC: } 40\end{array}$ & $\begin{array}{l}\text { BD: } 41(32-52) \\
\text { HC: } 36(30-47)\end{array}$ & All males & $\begin{array}{l}\text { BD: } 58 \pm 8.2 \\
H C: 57 \pm 8.1\end{array}$ & $P=0.567$ \\
\hline $\begin{array}{l}\text { Leucine } \\
\text { (Leu) } \mu \mathrm{M}\end{array}$ & $\begin{array}{l}\text { Yoshimi et al. } \\
2016(42)\end{array}$ & $\begin{array}{l}\text { BD: } 54 \\
\text { HC: } 40\end{array}$ & $\begin{array}{l}\text { BD: } 41(32-52) \\
\text { HC: } 36(30-47)\end{array}$ & All males & $\begin{array}{l}\text { BD: } 17 \pm 4.6 \\
\text { HC: } 16 \pm 3.9\end{array}$ & $P=0.267$ \\
\hline $\begin{array}{l}\text { Isoleucine } \\
\text { (Ile) } \mu \mathrm{M}\end{array}$ & $\begin{array}{l}\text { Yoshimi et al. } \\
2016(42)\end{array}$ & $\begin{array}{l}\text { BD: } 54 \\
\text { HC: } 40\end{array}$ & $\begin{array}{l}\text { BD: } 41(32-52) \\
\text { HC: } 36(30-47)\end{array}$ & All males & $\begin{array}{l}\text { BD: } 5.3 \pm 2.1 \\
\text { HC: } 4.6 \pm 1.5\end{array}$ & $P=0.098$ \\
\hline $\begin{array}{l}\text { Asparagine } \\
\text { (Asn) } \mu \mathrm{M}\end{array}$ & $\begin{array}{l}\text { Yoshimi et al. } \\
2016(42)\end{array}$ & $\begin{array}{l}\text { BD: } 54 \\
\text { HC: } 40\end{array}$ & $\begin{array}{l}\text { BD: } 41(32-52) \\
\text { HC: } 36(30-47)\end{array}$ & All males & $\begin{array}{l}\text { BD: } 7.0 \pm 1.1 \\
\text { HC: } 6.9 \pm 1.3\end{array}$ & $P=0.555$ \\
\hline Ornithine $\mu \mathrm{M}$ & $\begin{array}{l}\text { Yoshimi et al. } \\
2016(42)\end{array}$ & $\begin{array}{l}\text { BD: } 54 \\
\text { HC: } 40\end{array}$ & $\begin{array}{l}\text { BD: } 41(32-52) \\
\text { HC: } 36(30-47)\end{array}$ & All males & $\begin{array}{l}\text { BD: } 5.6 \pm 1.9 \\
\text { HC: } 5.2 \pm 1.0\end{array}$ & $P=0.173$ \\
\hline $\begin{array}{l}\text { Hypoxanthine } \\
\mu \mathrm{M}\end{array}$ & $\begin{array}{l}\text { Yoshimi et al. } \\
2016(42)\end{array}$ & $\begin{array}{l}\text { BD: } 54 \\
\text { HC: } 40\end{array}$ & $\begin{array}{l}\text { BD: } 41(32-52) \\
\text { HC: } 36 \text { (30-47) }\end{array}$ & All males & $\begin{array}{l}\text { BD: } 3.1 \pm 0.6 \\
\text { HC: } 2.9 \pm 0.5\end{array}$ & $P=0.146$ \\
\hline $\begin{array}{l}\text { Glutamine } \\
\text { (Gln) } \mu \mathrm{M}\end{array}$ & $\begin{array}{l}\text { Yoshimi et al. } \\
2016(42)\end{array}$ & $\begin{array}{l}\text { BD: } 54 \\
\text { HC: } 40\end{array}$ & $\begin{array}{l}\text { BD: } 41(32-52) \\
\text { HC: } 36(30-47)\end{array}$ & All males & $\begin{array}{l}\text { BD: } 711 \pm 66 \\
\text { HC: } 692 \pm 67\end{array}$ & $P=0.171$ \\
\hline $\begin{array}{l}\text { Lysine } \\
\text { (Lys) } \mu \mathrm{M}\end{array}$ & $\begin{array}{l}\text { Yoshimi et al. } \\
2016(42)\end{array}$ & $\begin{array}{l}\text { BD: } 54 \\
\text { HC: } 40\end{array}$ & $\begin{array}{l}\text { BD: } 41(32-52) \\
\text { HC: } 36(30-47)\end{array}$ & All males & $\begin{array}{l}\text { BD: } 36 \pm 7.0 \\
H C: 36 \pm 6.6\end{array}$ & $P=0.774$ \\
\hline $\begin{array}{l}\text { Methionine } \\
\text { (Met) } \mu \mathrm{M}\end{array}$ & $\begin{array}{l}\text { Yoshimi et al. } \\
2016(42)\end{array}$ & $\begin{array}{l}\text { BD: } 54 \\
\text { HC: } 40\end{array}$ & $\begin{array}{l}\text { BD: } 41(32-52) \\
\text { HC: } 36(30-47)\end{array}$ & All males & $\begin{array}{l}\text { BD: } 4.0 \pm 1.0 \\
\text { HC: } 4.0 \pm 1.0\end{array}$ & $P=0.698$ \\
\hline
\end{tabular}




\begin{tabular}{|l|l|l|l|l|c|c|}
\hline $\begin{array}{l}\text { Histidine } \\
(H i s) \mu M\end{array}$ & Yoshimi et al. & BD: 54 & BD: $41(32-52)$ & All males & BD: $12 \pm 1.5$ \\
HC: $12 \pm 1.5$
\end{tabular}

${ }^{a}:$ Median \pm SD, ${ }^{b}:$ Median (interquartile range) 
References

1. CARLSSON A, LINDQVIST M, MAGNUSSON T. 3,4-Dihydroxyphenylalanine and 5-hydroxytryptophan as reserpine antagonists Nature 1957; 180: 1200.

2. Abbott A. Neuroscience: the molecular wake-up call Nature $2007 ; 447: 368-370$.

3. Moher D, Liberati A, Tetzlaff J, Altman DG. Preferred reporting items for systematic reviews and meta-analyses: the PRISMA Statement Open Med 2009; 3: e123-e130.

4. Forlenza OV, Aprahamian I, Radanovic M, Talib LL, Camargo MZ, Stella F, Machado-Vieira R, Gattaz WF. Cognitive impairment in late-life bipolar disorder is not associated with Alzheimer's disease pathological signature in the cerebrospinal fluid Bipolar Disord 2016; 18: 63-70.

5. Sellgren CM, Kegel ME, Bergen SE, Ekman CJ, Olsson S, Larsson M, Vawter MP, Backlund L, Sullivan PF, Sklar P, Smoller JW, Magnusson PK, Hultman CM, Walther-Jallow L, Svensson Cl, Lichtenstein P, Schalling $M$, Engberg G, Erhardt S, Landen M. A genome-wide association study of kynurenic acid in cerebrospinal fluid: implications for psychosis and cognitive impairment in bipolar disorder Mol Psychiatry 2015.

6. Rolstad S, Jakobsson J, Sellgren C, Isgren A, Ekman CJ, Bjerke M, Blennow K, Zetterberg H, Palsson E, Landen M. CSF neuroinflammatory biomarkers in bipolar disorder are associated with cognitive impairment Eur Neuropsychopharmacol 2015; 25: 1091-1098.

7. Rolstad S, Jakobsson J, Sellgren C, Ekman CJ, Blennow K, Zetterberg H, Palsson E, Landen M. Cognitive performance and cerebrospinal fluid biomarkers of neurodegeneration: a study of patients with bipolar disorder and healthy controls PLoS One 2015; 10: e0127100.

8. Sanderson S, Tatt ID, Higgins JP. Tools for assessing quality and susceptibility to bias in observational studies in epidemiology: a systematic review and annotated bibliography Int J Epidemiol 2007; 36: 666-676.

9. Doran AR, Rubinow DR, Roy A, Pickar D. CSF somatostatin and abnormal response to dexamethasone administration in schizophrenic and depressed patients Arch Gen Psychiatry 1986; 43: 365-369.

10. Cramer H, Goodwin FK, Post RM, Bunney WE, Jr. Effects of probenecid and exercise on cerebrospinal-fluid cyclic A.M.P. in affective illness Lancet 1972; 1: 1346-1347.

11. Subrahmanyam S. Role of biogenic amines in certain pathological conditions Brain Res 1975; 87: 355-362.

12. Koslow SH, Maas JW, Bowden CL, Davis JM, Hanin I, Javaid J. CSF and urinary biogenic amines and metabolites in depression and mania. A controlled, univariate analysis Arch Gen Psychiatry 1983; 40: 999-1010. 
13. Gerner RH, Fairbanks L, Anderson GM, Young JG, Scheinin M, Linnoila M, Hare TA, Shaywitz BA, Cohen DJ. CSF neurochemistry in depressed, manic, and schizophrenic patients compared with that of normal controls Am J Psychiatry 1984; 141: 1533-1540.

14. Berrettini WH, Nurnberger JI, Jr., Narrow W, Simmons-Alling S, Gershon ES. Cerebrospinal fluid studies of bipolar patients with and without a history of suicide attempts Ann N Y Acad Sci 1986; 487: 197-201.

15. Mann JJ, Oquendo MA, Watson KT, Boldrini M, Malone KM, Ellis SP, Sullivan G, Cooper TB, Xie S, Currier D. Anxiety in major depression and cerebrospinal fluid free gamma-aminobutyric acid Depress Anxiety 2014; 31: 814-821.

16. Anderson GM, Gerner RH, Cohen DJ, Fairbanks L. Central tryptamine turnover in depression, schizophrenia, and anorexia: measurement of indoleacetic acid in cerebrospinal fluid Biol Psychiatry 1984; 19: 1427-1435.

17. Sjostrom R, Roos BE. 5-Hydroxyindolacetic acid and homovanillic acid in cerebrospinal fluid in manic-depressive psychosis Eur J Clin Pharmacol 1972; 4: 170-176.

18. Palsson E, Sellgren C, Ryden E, Kizza R, Pelanis A, Zetterberg H, Blennow K, Landen M. Cerebrospinal fluid monoamine metabolite profiles in bipolar disorder, ADHD, and controls J Neural Transm (Vienna) 2017.

19. Poltorak M, Frye MA, Wright R, Hemperly JJ, George MS, Pazzaglia PJ, Jerrels SA, Post RM, Freed WJ. Increased neural cell adhesion molecule in the CSF of patients with mood disorder J Neurochem 1996; 66: 1532-1538.

20. Dencker SJ, Malm U. Protein pattern of cerebrospinal fluid in mental disease Acta Psychiatr Scand Suppl 1968; 203: 105-109.

21. Soderlund J, Olsson SK, Samuelsson M, Walther-Jallow L, Johansson C, Erhardt S, Landen M, Engberg G. Elevation of cerebrospinal fluid interleukin-1ss in bipolar disorder J Psychiatry Neurosci 2011; 36: 114-118.

22. Isgren A, Jakobsson J, Palsson E, Ekman CJ, Johansson AG, Sellgren C, Blennow K, Zetterberg H, Landen M. Increased cerebrospinal fluid interleukin-8 in bipolar disorder patients associated with lithium and antipsychotic treatment Brain Behav Immun 2015; 43: 198-204.

23. Jakobsson J, Bjerke M, Sahebi S, Isgren A, Ekman CJ, Sellgren C, Olsson B, Zetterberg H, Blennow K, Palsson $\mathrm{E}$, Landen $\mathrm{M}$. Monocyte and microglial activation in patients with mood-stabilized bipolar disorder J Psychiatry Neurosci 2015; 40: 250-258.

24. Vawter MP, Frye MA, Hemperly JJ, VanderPutten DM, Usen N, Doherty P, Saffell JL, Issa F, Post RM, Wyatt RJ, Freed WJ. Elevated concentration of N-CAM VASE isoforms in schizophrenia J Psychiatr Res 2000; 34: 25-34.

25. Hidese S, Hattori K, Sasayama D, Miyakawa T, Matsumura R, Yokota Y, Ishida I, Matsuo J, Noda T, Yoshida S, Teraishi T, Hori H, Ota M, Kunugi H. Cerebrospinal fluid neural cell adhesion molecule levels and their correlation with clinical variables in patients with schizophrenia, bipolar disorder, and major depressive disorder Prog Neuropsychopharmacol Biol Psychiatry 2017; 76: 12-18. 
26. Gerner RH, Wilkins JN. CSF cortisol in patients with depression, mania, or anorexia nervosa and in normal subjects Am J Psychiatry 1983; 140: 92-94.

27. Berrettini WH, Nurnberger JI, Jr., Simmons-Alling S. Growth hormone releasing factor in human cerebrospinal fluid Psychiatry Res 1987; 22: 141-147.

28. Bumb JM, Enning F, Mueller JK, van der List T, Rohleder C, Findeisen P, Noelte I, Schwarz E, Leweke FM. Differential melatonin alterations in cerebrospinal fluid and serum of patients with major depressive disorder and bipolar disorder Compr Psychiatry 2016; 68: 34-39.

29. George MS, Rosenstein D, Rubinow DR, Kling MA, Post RM. CSF magnesium in affective disorder: lack of correlation with clinical course of treatment Psychiatry Res 1994; 51: 139-146.

30. Frye MA, Gary KA, Marangell LB, George MS, Callahan AM, Little JT, Huggins T, Cora-Locatelli G, Osuch EA, Winokur A, Post RM. CSF thyrotropin-releasing hormone gender difference: implications for neurobiology and treatment of depression J Neuropsychiatry Clin Neurosci 1999; 11: 349-353.

31. George MS, Guidotti A, Rubinow D, Pan B, Mikalauskas K, Post RM. CSF neuroactive steroids in affective disorders: pregnenolone, progesterone, and DBI Biol Psychiatry 1994; 35: 775-780.

32. Jakobsson J, Zetterberg $\mathrm{H}$, Blennow K, Johan EC, Johansson AG, Landen M. Altered concentrations of amyloid precursor protein metabolites in the cerebrospinal fluid of patients with bipolar disorder Neuropsychopharmacology 2013; 38: 664-672.

33. Jakobsson J, Stridsberg M, Zetterberg H, Blennow K, Ekman CJ, Johansson AG, Sellgren C, Landen M. Decreased cerebrospinal fluid secretogranin II concentrations in severe forms of bipolar disorder J Psychiatry Neurosci 2013; 38: E21-E26.

34. Naber D, Pickar D, Post RM, van Kammen DP, Waters RN, Ballenger JC, Goodwin FK, Bunney WE, Jr. Endogenous opioid activity and beta-endorphin immunoreactivity in CSF of psychiatric patients and normal volunteers Am J Psychiatry 1981; 138: 1457-1462.

35. Jakobsson J, Bjerke M, Ekman CJ, Sellgren C, Johansson AG, Zetterberg H, Blennow K, Landen M. Elevated concentrations of neurofilament light chain in the cerebrospinal fluid of bipolar disorder patients Neuropsychopharmacology 2014; 39: 2349-2356.

36. Berrettini WH, Rubinow DR, Nurnberger JI, Jr., Simmons-Alling S, Post RM, Gershon ES. CSF substance $P$ immunoreactivity in affective disorders Biol Psychiatry 1985; 20: 965-970.

37. Zetterberg H, Jakobsson J, Redsater M, Andreasson U, Palsson E, Ekman CJ, Sellgren C, Johansson AG, Blennow K, Landen M. Blood-cerebrospinal fluid barrier dysfunction in patients with bipolar disorder in relation to antipsychotic treatment Psychiatry Res 2014; 217: 143-146.

38. Gerner RH, Yamada T. Altered neuropeptide concentrations in cerebrospinal fluid of psychiatric patients Brain Res 1982; 238: 298-302.

39. Verbanck PM, Lotstra F, Gilles C, Linkowski P, Mendlewicz J, Vanderhaeghen JJ. Reduced cholecystokinin immunoreactivity in the cerebrospinal fluid of patients with psychiatric disorders Life Sci 1984; 34: 67-72. 
40. Rubinow DR, Gold PW, Post RM, Ballenger JC, Cowdry R, Bollinger J, Reichlin S. CSF somatostatin in affective illness Arch Gen Psychiatry 1983; 40: 409-412.

41. Palsson E, Jakobsson J, Sodersten K, Fujita Y, Sellgren C, Ekman CJ, Agren H, Hashimoto K, Landen M. Markers of glutamate signaling in cerebrospinal fluid and serum from patients with bipolar disorder and healthy controls Eur Neuropsychopharmacol 2015; 25: 133-140.

42. Yoshimi N, Futamura T, Bergen SE, Iwayama Y, Ishima T, Sellgren C, Ekman CJ, Jakobsson J, Palsson E, Kakumoto K, Ohgi Y, Yoshikawa T, Landen M, Hashimoto K. Cerebrospinal fluid metabolomics identifies a key role of isocitrate dehydrogenase in bipolar disorder: evidence in support of mitochondrial dysfunction hypothesis Mol Psychiatry 2016.

43. Regenold WT, Kling MA, Hauser P. Elevated sorbitol concentration in the cerebrospinal fluid of patients with mood disorders Psychoneuroendocrinology 2000; 25: 593-606.

44. Spitzer RL, Endicott J, Robins E. Research diagnostic criteria Psychopharmacol Bull 1975; 11: 22-25.

45. Hasler G, Drevets WC, Gould TD, Gottesman II, Manji HK. Toward constructing an endophenotype strategy for bipolar disorders Biol Psychiatry 2006; 60: 93-105.

46. Manji HK, Quiroz JA, Payne JL, Singh J, Lopes BP, Viegas JS, Zarate CA. The underlying neurobiology of bipolar disorder World Psychiatry 2003; 2: 136-146.

47. Berrettini WH, Nurnberger JI, Jr., Scheinin M, Seppala T, Linnoila M, Narrow W, Simmons-Alling S, Gershon ES. Cerebrospinal fluid and plasma monoamines and their metabolites in euthymic bipolar patients Biol Psychiatry 1985; 20: 257-269.

48. Berrettini WH, Nurnberger JI, Jr., Hare TA, Simmons-Alling S, Gershon ES. CSF GABA in euthymic manic-depressive patients and controls Biol Psychiatry 1986; 21: 844-846.

49. Inada T, Inagaki A. Psychotropic dose equivalence in Japan Psychiatry Clin Neurosci 2015; 69: 440447.

50. Grunze H, Vieta E, Goodwin GM, Bowden C, Licht RW, Moller HJ, Kasper S. The World Federation of Societies of Biological Psychiatry (WFSBP) guidelines for the biological treatment of bipolar disorders: update 2012 on the long-term treatment of bipolar disorder World J Biol Psychiatry 2013; 14: 154-219.

51. Luykx JJ, Bakker SC, van BL, Vinkers CH, Smeenk HE, Visser WF, Verhoeven-Duif NM, Strengman E, Buizer-Voskamp JE, de GL, van Dongen EP, Borgdorff P, Bruins P, de Koning TJ, Kahn RS, Ophoff RA. $D$-amino acid aberrations in cerebrospinal fluid and plasma of smokers Neuropsychopharmacology 2013; 38: 2019-2026.

52. Jakobsson J, Palsson E, Sellgren C, Rydberg F, Ekman A, Zetterberg H, Blennow K, Landen M. CACNA1C polymorphism and altered phosphorylation of tau in bipolar disorder Br J Psychiatry 2015.

53. Secunda SK, Cross CK, Koslow S, Katz MM, Kocsis J, Maas JW, Landis H. Biochemistry and suicidal behavior in depressed patients Biol Psychiatry 1986; 21: 756-767. 
54. Gjerris A. Baseline studies on transmitter substances in cerebrospinal fluid in depression Acta Psychiatr Scand Suppl 1988; 346: 1-35.

55. Maccarrone G, Ditzen C, Yassouridis A, Rewerts C, Uhr M, Uhlen M, Holsboer F, Turck CW. Psychiatric patient stratification using biosignatures based on cerebrospinal fluid protein expression clusters J Psychiatr Res 2013; 47: 1572-1580. 